Prepared in cooperation with the U.S. Environmental Protection Agency

\title{
Annual Trace-Metal Load Estimates and Flow-Weighted Concentrations of Cadmium, Lead, and Zinc, in the Spokane River Basin, Idaho and Washington, 1999-2004
}

Scientific Investigations Report 2006-5188 



\section{Annual Trace-Metal Load Estimates and Flow-Weighted Concentrations of Cadmium, Lead, and Zinc, in the Spokane River Basin, Idaho and Washington, 1999-2004}

By Mary M. Donato

Prepared in cooperation with the U.S. Environmental Protection Agency

Scientific Investigations Report 2006-5188 


\section{U.S. Department of the Interior \\ DIRK A. KEMPTHORNE, Secretary \\ U.S. Geological Survey \\ P. Patrick Leahy, Acting Director}

\section{U.S. Geological Survey, Reston, Virginia: 2006}

For product and ordering information:

World Wide Web: http://www.usgs.gov/pubprod

Telephone: 1-888-ASK-USGS

For more information on the USGS--the Federal source for science about the Earth, its natural and living resources, natural hazards, and the environment:

World Wide Web: http://www.usgs.gov

Telephone: 1-888-ASK-USGS

Any use of trade, product, or firm names is for descriptive purposes only and does not imply endorsement by the U.S. Government.

Although this report is in the public domain, permission must be secured from the individual copyright owners to reproduce any copyrighted materials contained within this report.

Suggested citation:

Donato, M.M., 2006, Annual trace-metal load estimates and flow-weighted concentrations of cadmium, lead, and zinc in the Spokane River Basin, Idaho and Washington, 1999-2004: U.S. Geological Survey Scientific Investigations Report 2006-5188, $38 \mathrm{p}$. 


\section{Contents}

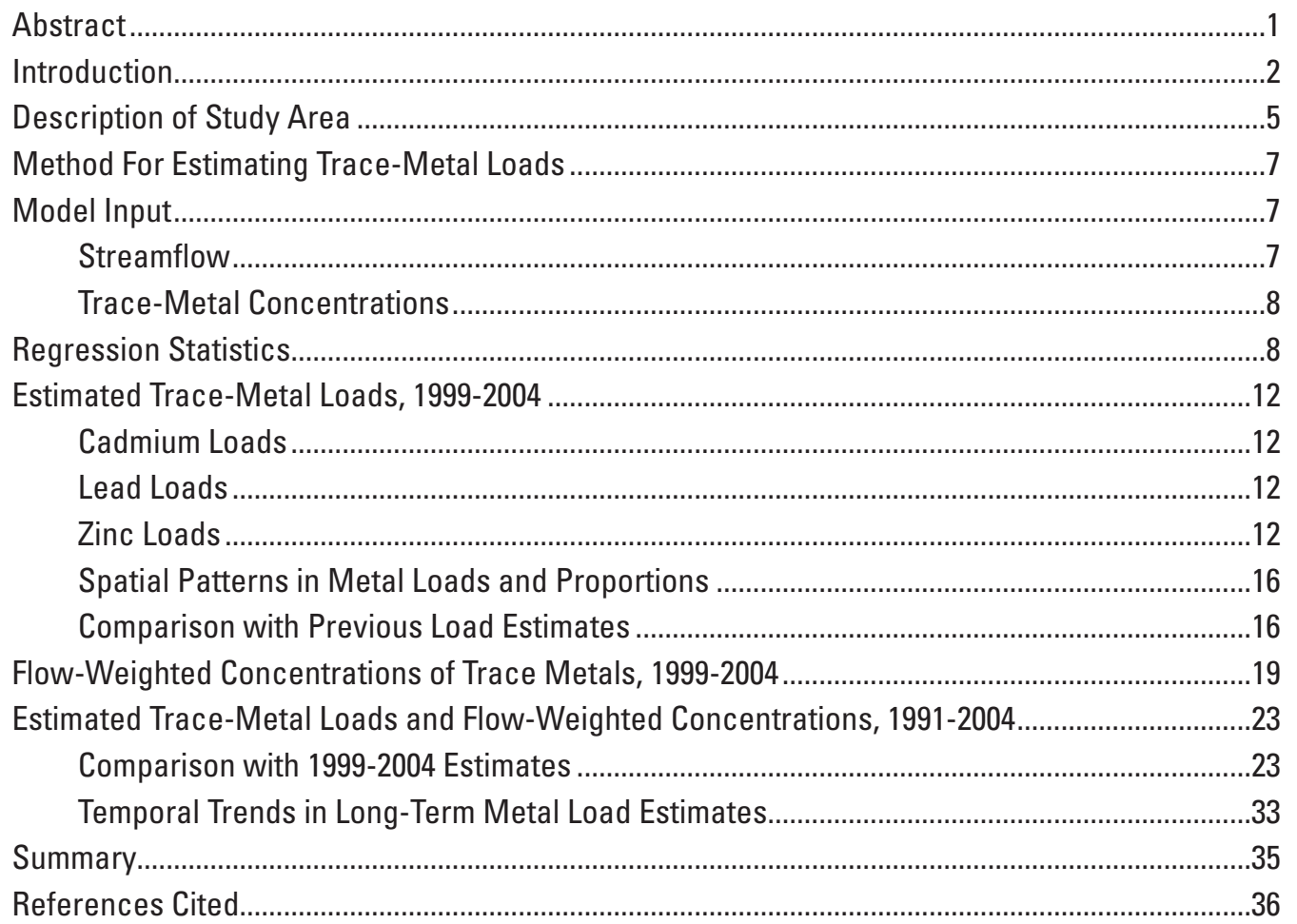

\section{Figures}

Figure 1. Map showing locations of streamflow-gaging stations and Bunker Hill Box, including Operable Units 1 and 2, in the Spokane and Coeur d'Alene River basins, Idaho and Washington .....

Figure 2. Map showing locations of streamflow-gaging stations on and near the South Fork Coeur d'Alene River, Idaho

Figure 3. Diagram showing relative locations and hydrologic relationships among 10 streamflow-gaging stations in the Spokane River basin, Idaho and Washington ... 6

Figure 4. Graphs showing relation between trace-metal concentrations and streamflow at U.S. Geological Survey streamflow-gaging station 12413210, South Fork Coeur d'Alene River at Elizabeth Park, near Kellogg, Idaho, water years 1999-2004.

Figure 5. Graphs showing mean annual estimated dissolved and total trace-metal loads and mean streamflow at 10 streamflow-gaging stations in the Spokane River basin, Idaho and Washington, water years 1999-2004

Figure 6. Graphs showing mean annual flow-weighted concentrations of trace metals and mean streamflow at 10 streamflow-gaging stations in the Spokane River basin, Idaho and Washington, water years 1999-2004

Figure 7. Graphs showing estimated long-term mean annual dissolved and total trace-metal loads and mean streamflow at four streamflow-gaging stations in the Spokane River basin, Idaho 


\section{Figures-Continued}

Figure 8. Graphs showing mean annual flow-weighted concentrations of dissolved and total cadmium, lead, and zinc and mean annual streamflow at four streamflow-gaging stations in the Spokane River basin, Idaho.

Figure 9. Graphs showing comparison of short- and long-term trace-metal load estimates at four streamflow-gaging stations in the Spokane River basin, Idaho

Figure 10. Graphs showing estimated flow-weighted concentration of dissolved and total cadmium and mean annual streamflow at South Fork Coeur d'Alene River at Pinehurst, water years 1991-2004 and North Fork Coeur d'Alene River at Enaville, Idaho, water years 1992-2004

\section{Tables}

Table 1. Streamflow-gaging stations in the Spokane River basin, Idaho and Washington, where streamflow and water-quality samples were collected to estimate flow-weighted concentrations and cadmium, lead, and zinc loads, water years 1991-2004

Table 2. Regression coefficients and coefficients of determination $\left(R^{2}\right)$ used to estimate dissolved and total cadmium, lead, and zinc loads at 10 streamflow-gaging stations in the Spokane River basin, Idaho and Washington, water years 1999-2004

Table 3. Estimated mean annual trace-metal loads for 10 streamflow-gaging stations in the Spokane River basin, Washington and Idaho, water years 1999-2004.

Table 4. Comparison of trace-metal load estimates for water years 1999-2001 (this study) with estimates by Clark (2002) for nine streamflow-gaging stations in the Spokane River basin, Idaho and Washington

Table 5. Estimated mean annual flow-weighted concentrations of trace metals for 10 streamflow-gaging stations in the Spokane River basin, Idaho and Washington, water years 1999-2004

Table 6. Regression coefficients and coefficients of determination $\left(R^{2}\right)$ for load models used to estimate dissolved and total cadmium, lead, and zinc loads at four streamflow-gaging stations in the Spokane River basin, Idaho

Table 7. Estimated long-term mean annual trace-metal loads and flow-weighted concentrations of cadmium, lead, and zinc at four streamflow-gaging stations in the Spokane River basin, Idaho

Table 8. Comparison of short- and long-term trace-metal load estimates for four streamflow-gaging stations in the Spokane River basin, Idaho.

Table 9. Comparison of trend analysis results for trace-metal loads and flow-weighted concentrations based on the Mann-Kendall test and LOADEST regression analysis for four streamflow-gaging stations in the Spokane River basin, Idaho, water years 1991-2004 


\section{Conversion Factors and Datums}

Conversion Factors

\begin{tabular}{lcl}
\hline \multicolumn{1}{c}{ Multiply } & By & \multicolumn{1}{c}{ To obtain } \\
\hline cubic foot per second $\left(\mathrm{ft}^{3} / \mathrm{s}\right)$ & 0.02832 & cubic meter per second \\
cubic meter per second $\left(\mathrm{m}^{3} / \mathrm{s}\right)$ & 70.07 & acre-foot per day \\
kilogram $(\mathrm{kg})$ & 2.205 & pound avoirdupois \\
kilogram per day $(\mathrm{kg} / \mathrm{d})$ & 2.205 & pound avoirdupois per day \\
kilogram per year $(\mathrm{kg} / \mathrm{y})$ & 2.205 & pound avoirdupois per year \\
square mile $\left(\mathrm{mi}^{2}\right)$ & 259.0 & hectare \\
square mile $\left(\mathrm{mi}^{2}\right)$ & 2.590 & square kilometer \\
\hline
\end{tabular}

Temperature in degrees Celsius $\left({ }^{\circ} \mathrm{C}\right)$ may be converted to degrees Fahrenheit $\left({ }^{\circ} \mathrm{F}\right)$ as follows:

${ }^{\circ} \mathrm{F}=\left(1.8 x^{\circ} \mathrm{C}\right)+32$.

Datums

Vertical coordinate information is referenced to the North American Vertical Datum of 1988

(NAVD 88).

Horizontal coordinate information is referenced to the North American Datum of 1983 (NAD 83).

Altitude, as used in this report, refers to distance above the vertical datum. 
This page left intentionally blank. 


\section{Annual Trace-Metal Load Estimates and Flow-Weighted Concentrations of Cadmium, Lead, and Zinc in the Spokane River Basin, Idaho and Washington, 1999-2004}

By Mary M. Donato

\section{Abstract}

Streamflow and trace-metal concentration data collected at 10 locations in the Spokane River basin of northern Idaho and eastern Washington during 1999-2004 were used as input for the U.S. Geological Survey software, LOADEST, to estimate annual loads and mean flow-weighted concentrations of total and dissolved cadmium, lead, and zinc.

Cadmium composed less than 1 percent of the total metal load at all stations; lead constituted from 6 to 42 percent of the total load at stations upstream from Coeur d'Alene Lake and from 2 to 4 percent at stations downstream of the lake. Zinc composed more than 90 percent of the total metal load at 6 of the 10 stations examined in this study.

Trace-metal loads were lowest at the station on Pine Creek below Amy Gulch, where the mean annual total cadmium load for 1999-2004 was 39 kilograms per year $(\mathrm{kg} / \mathrm{yr})$, the mean estimated total lead load was about 1,700 $\mathrm{kg} / \mathrm{yr}$, and the mean annual total zinc load was $14,000 \mathrm{~kg} / \mathrm{yr}$. The trace-metal loads at stations on North Fork Coeur d'Alene River at Enaville, Ninemile Creek, and Canyon Creek also were relatively low.

Trace-metal loads were highest at the station at Coeur d'Alene River near Harrison. The mean annual total cadmium load was $3,400 \mathrm{~kg} / \mathrm{yr}$, the mean total lead load was 240,000 $\mathrm{kg} / \mathrm{yr}$, and the mean total zinc load was $510,000 \mathrm{~kg} / \mathrm{yr}$ for 1999-2004. Trace-metal loads at the station at South Fork Coeur d'Alene River near Pinehurst and the three stations on the Spokane River downstream of Coeur d'Alene Lake also were relatively high. Differences in metal loads, particularly lead, between stations upstream and downstream of Coeur d'Alene Lake likely are due to trapping and retention of metals in lakebed sediments.

LOADEST software was used to estimate loads for water years 1999-2001 for many of the same sites discussed in this report. Overall, results from this study and those from a previous study are in good agreement. Observed differences between the two studies are attributable to streamflow differences in the two regression models, 1999-2001 and 1999-2004.
Flow-weighted concentrations (FWCs) calculated from the estimated loads for 1999-2004 were examined to aid interpretation of metal load estimates, which were influenced by large spatial and temporal variations in streamflow. FWCs of total cadmium ranged from 0.04 micrograms per liter $(\mu \mathrm{g} / \mathrm{L})$ at Enaville to $14 \mu \mathrm{g} / \mathrm{L}$ at Ninemile Creek. Total lead FWCs were lowest at Long Lake $(1.3 \mu \mathrm{g} / \mathrm{L})$ and highest at Ninemile Creek $(120 \mu \mathrm{g} / \mathrm{L})$. Elevated total lead FWCs at Harrison confirmed that the high total lead loads at this station were not simply due to higher streamflow. Conversely, relatively low total lead loads combined with high total lead FWCs at Ninemile and Canyon Creeks reflected low streamflow but high concentrations of total lead. Very low total lead FWCs $(1.3$ to $2.7 \mu \mathrm{g} / \mathrm{L})$ at the stations downstream of Coeur d'Alene Lake are a result both of deposition of lead-laden sediments in the lake and dilution by additional streamflow. Total zinc FWCs also demonstrated the effect of streamflow on load calculations, and highlighted source areas for zinc in the basin. Total zinc FWCs at Canyon and Ninemile Creeks, 1,600 $\mu \mathrm{g} / \mathrm{L}$ and 2,200 $\mu \mathrm{g} / \mathrm{L}$, respectively, were by far the highest in the basin but contributed among the lowest total zinc loads due to their relatively low streamflow. Total zinc FWCs ranged from 38 to $67 \mu \mathrm{g} / \mathrm{L}$ at stations downstream of Coeur d'Alene Lake, but total zinc load estimates at these stations were relatively high because of high mean streamflow compared to other stations in the basin.

Long-term regression models for 1991 to 2003 or 2004 were developed and annual trace-metal loads and FWCs were estimated for Pinehurst, Enaville, Harrison, and Post Falls to better understand the variability of metal loading with time. Long-term load estimates are similar to the results for 1999-2004 in terms of spatial distribution of metal loads throughout the basin.

LOADEST results for 1991-2004 indicated that statistically significant downward temporal trends for dissolved and total cadmium, dissolved zinc, and total lead were occurring at Pinehurst, Enaville, Harrison, and Post Falls. Additionally, data for Enaville and Post Falls showed significant downward trends for dissolved lead and total zinc loads; Harrison total zinc loads also decreased with time. The 
Mann-Kendall trend test results agreed with the LOADEST trend results in most cases, but gave contradictory results for total zinc at Pinehurst and at Post Falls.

Long- and short-term load and flow-weighted concentration estimates yielded valuable information about metal storage and transport processes, and demonstrated that water quality data are a great aid in understanding these processes.

\section{Introduction}

Since the late 1800s, mining and ore-processing activities in the South Fork Coeur d'Alene River basin have altered the water quality, aquatic biological, and hydrologic conditions in the 6,680-mi ${ }^{2}$ Spokane River basin of northern Idaho and eastern Washington (fig. 1). Historical ore-processing activities resulted in large quantities of metal-rich tailings that were placed in and along streams (Long, 1998). The tailings have produced, and continue to produce, trace-metalcontaminated water (Hartz, 1993; Woods, 2001a; Woods, 2001b) and extensive deposits of trace-metal-contaminated sediment throughout the South Fork Coeur d'Alene River basin, the channel and flood plain of the main-stem Coeur d'Alene River (Spruill, 1993; Fousek, 1996; Bookstrom and others, 2001), and the lakebed of Coeur d'Alene Lake (Horowitz and others, 1995; Woods and Beckwith, 1997). Annual snowmelt runoff, frequent rain-on-snow events, and occasional floods continue to transport and redistribute tracemetal-contaminated sediments throughout the Coeur d'Alene River basin, into the Spokane River of eastern Washington (Maret and Skinner, 2000; Grosbois and others, 2001), and as far downstream as the Columbia River (Bortleson and others, 1994). The National Sediment Inventory (U.S. Environmental Protection Agency [USEPA], 1997) identified the Coeur d'Alene River and Lake as "areas of probable concern for sediment contamination," the most severe contamination category in their assessment.

In 1998, USEPA initiated a Remedial Investigation/ Feasibility Study (RI/FS) of the Spokane River basin under the authority of the Comprehensive Environmental Response, Compensation, and Liability Act (CERCLA) of 1980, which requires USEPA to evaluate contaminant release, fate, and transport. The Remedial Investigation (RI) phase involves data collection to characterize site conditions, development of conceptual models, determination of the nature and extent of trace-element contamination, and risk assessment for human health and the environment. The RI phase is followed by the Feasibility Study (FS) phase where remedial action alternatives are developed and evaluated.

Considerable effort is underway to mitigate the adverse environmental effects of past mining in the basin, primarily in the South Fork Coeur d'Alene River valley and its tributaries (Beckwith, 1998). The USEPA is directing cleanup of a Superfund site surrounding the defunct Bunker Hill Mine and ore-processing complex in Kellogg, Idaho (figs. 1 and 2). The State of Idaho, other Federal agencies, and the mining industry also are conducting site-specific sediment-removal, reclamation, and stream-channel rehabilitation projects.

The USEPA is evaluating environmental contamination and remediation options in mining-affected areas outside the Superfund site in areas of the lower Coeur d'Alene River, its flood plain and adjacent wetlands, and the lakebed of Coeur d'Alene Lake (Beckwith, 1998). In addition, the USEPA and the Idaho Department of Environmental Quality currently are under court order to develop Total Maximum Daily Loads for a number of water bodies that do not support one or more designated uses in the Spokane River basin because of tracemetal contamination.

In support of these activities, streamflow and tracemetal chemistry data collected by the U.S. Geological Survey (USGS) during several previous and ongoing scientific studies at 10 USGS streamflow-gaging stations in the Spokane River basin were compiled and analyzed (table 1; figs. 1, 2). The data then were used to estimate annual trace-metal loads at the 10 stations for water years (WY) 1999-2003 or 1999-2004. Trace-metal loads for WY 1991-2003 or 1991-2004 also were estimated at four of the stations. The purpose of this report is to present and describe the results of the load estimations of dissolved and total cadmium $(\mathrm{Cd})$, lead $(\mathrm{Pb})$, and zinc $(\mathrm{Zn})$ in numerous stream reaches in the Spokane River basin, Idaho and Washington, and to discuss inferences about metal transport and storage processes indicated by these results. The estimates in this study also were compared to earlier estimates of trace metal loads in the Spokane River basin as reported by Clark (2003). 


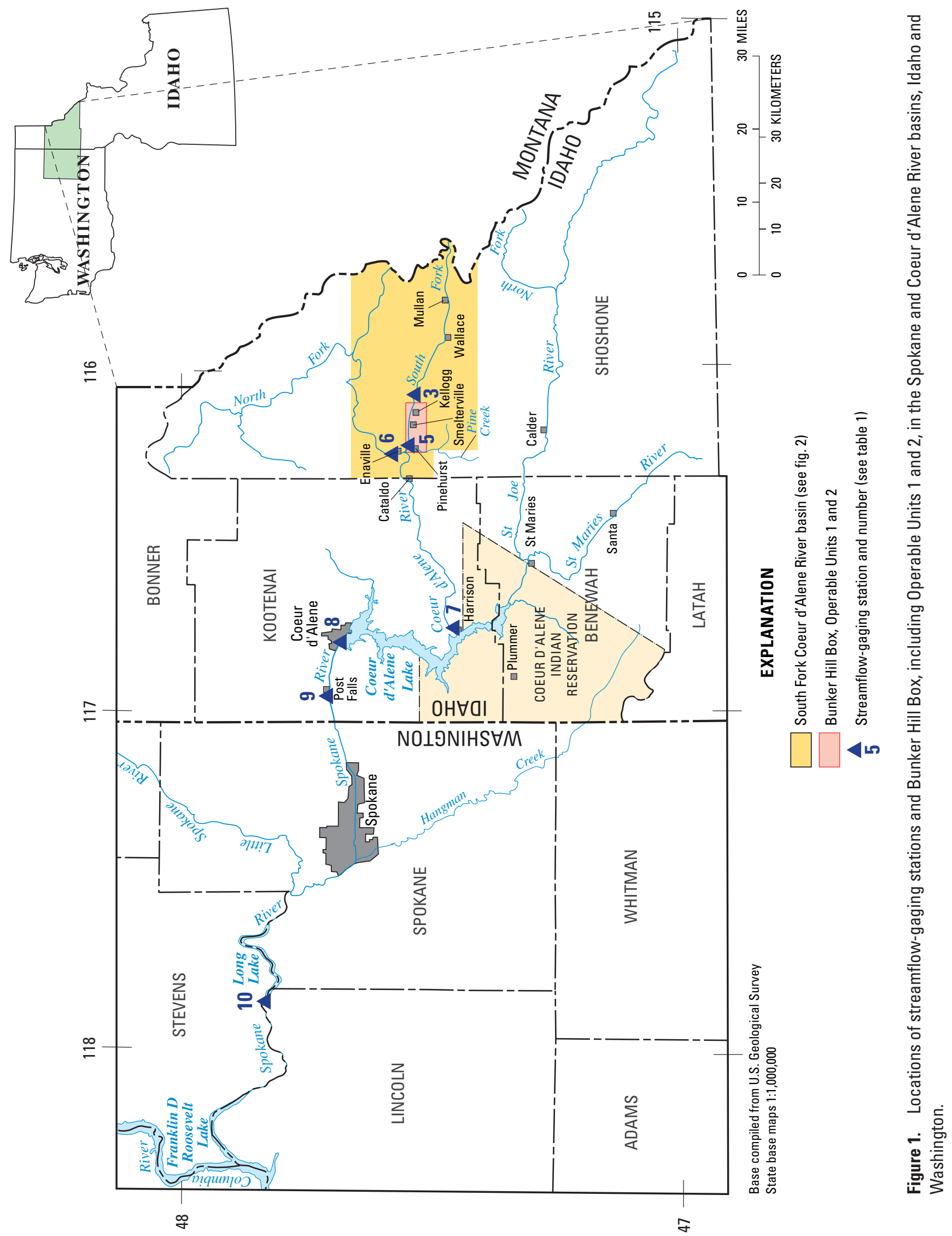



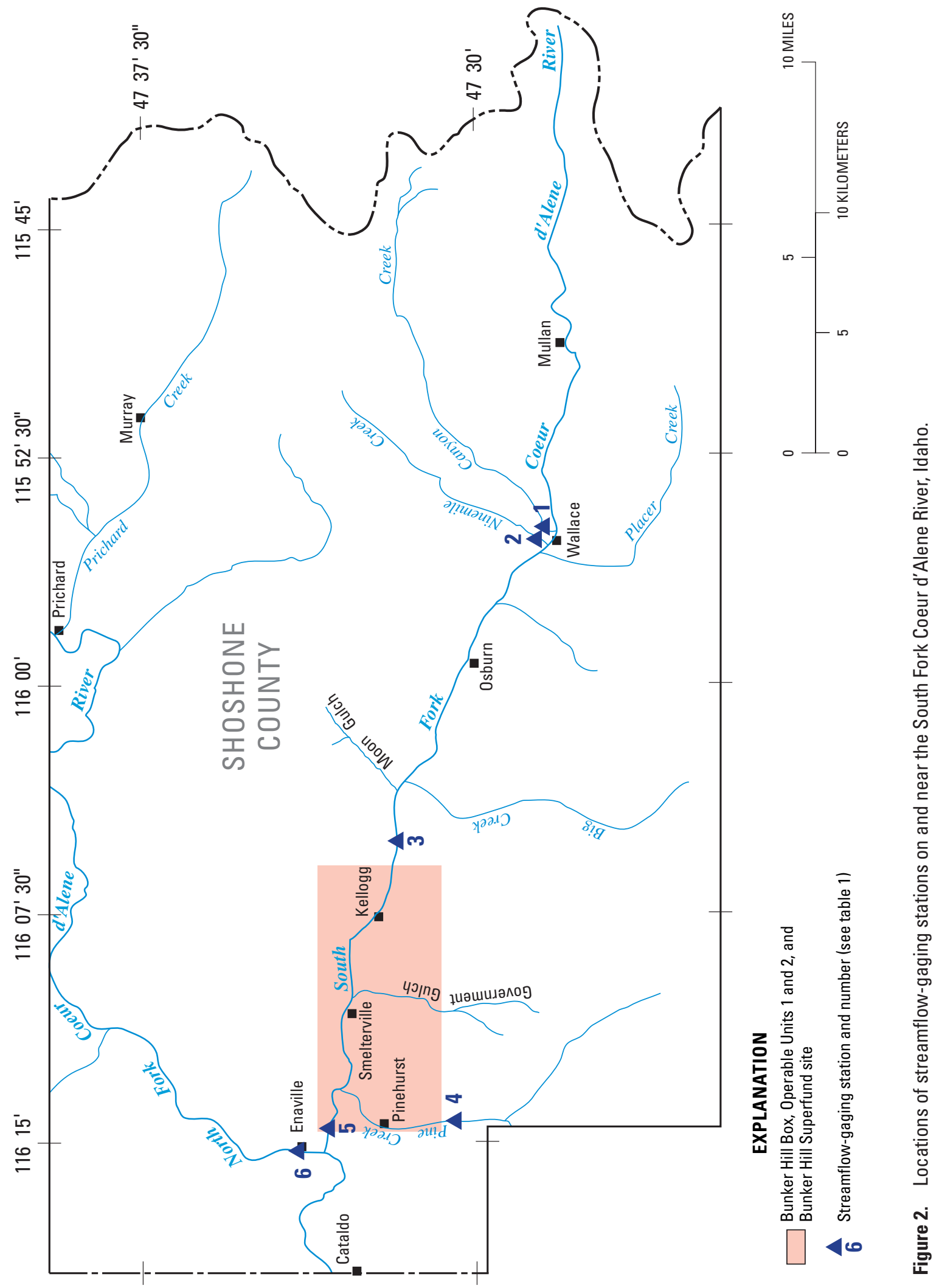
Table 1. Streamflow-gaging stations in the Spokane River basin, Idaho and Washington, where streamflow and water-quality samples were collected to estimate flow-weighted concentrations and cadmium, lead, and zinc loads, water years 1991-2004.

[Gaging station locations are shown in figures 1 and 2 . Type of streamflow record: C, continuous; S. simulated. Number of samples used in estimation: some samples did not include all constituents. Abbreviations: USGS, U.S. Geological Survey; ID, Idaho; WA, Washington]

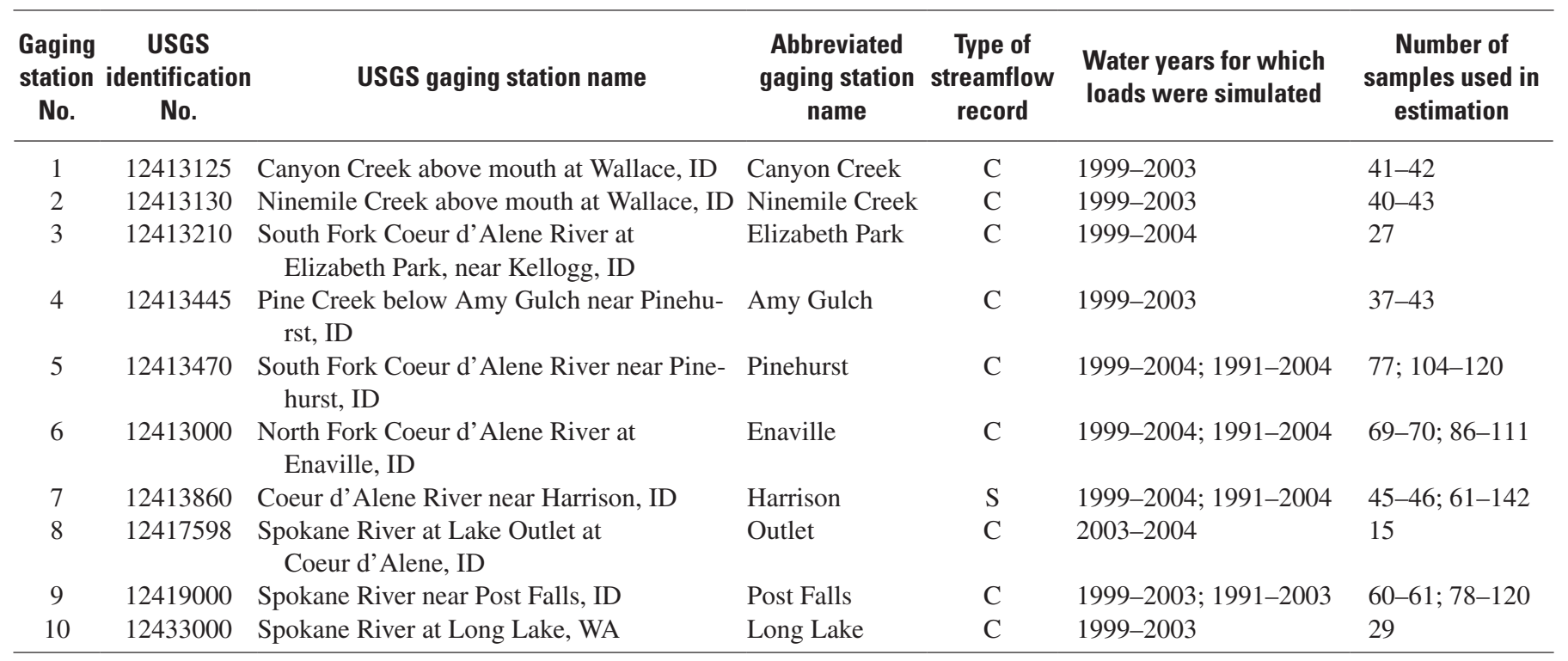

\section{Description of Study Area}

The occurrence and transport of trace metals in the Spokane River basin are controlled primarily by the metal source and input rate, the tendency of metals to adhere to sediment, and the transport of water and sediment through the basin. Primary sources of trace metals to the South Fork Coeur d'Alene, Coeur d'Alene, and Spokane Rivers include headwater streams, tributary inflows, ground-water inflow, overland runoff from flood plains, and erosion of streambank and streambed materials. Once trace metals are mobilized in an aquatic system, they can be redistributed in streams and rivers, especially during high streamflow when transport is at a maximum.

Figure 3 is a schematic diagram showing relative locations and hydrologic relationships among the 10 sites. Stations 1 and 2, referred to as Canyon Creek and Ninemile Creek, are on tributaries to the South Fork Coeur d'Alene River. Station 3, referred to as Elizabeth Park, is on the South Fork Coeur d'Alene River at Elizabeth Park, Idaho.
These three sites are upstream of the area designated by the USEPA as Operable Unit 2 (OU2). Station 4, referred to as Amy Gulch, is on Pine Creek, a tributary to the South Fork Coeur d'Alene River whose mouth is in OU2; however, the monitoring station is upstream of the OU2 boundary. Station 5, referred to as Pinehurst, near Pinehurst, Idaho, is on the South Fork Coeur d'Alene River downstream of the mouth of Pine Creek and in OU2. Station 6, referred to as Enaville, at Enaville, Idaho, is on the North Fork Coeur d'Alene River, which drains a part of the basin where minimal mining activity has taken place. Station 7, referred to as Harrison, near Harrison, Idaho, is on the Coeur d'Alene River downstream of the confluence of the North Fork and South Fork Coeur d'Alene Rivers. Because it represents the accumulated flow from the entire Coeur d'Alene River basin the Harrison site is important for monitoring metals carried into Coeur d'Alene Lake. Stations 8, 9, and 10 (referred to as Outlet, Post Falls, and Long Lake, respectively) are downstream of Coeur d'Alene Lake, on the mainstem Spokane River (figs. 1, 2). 


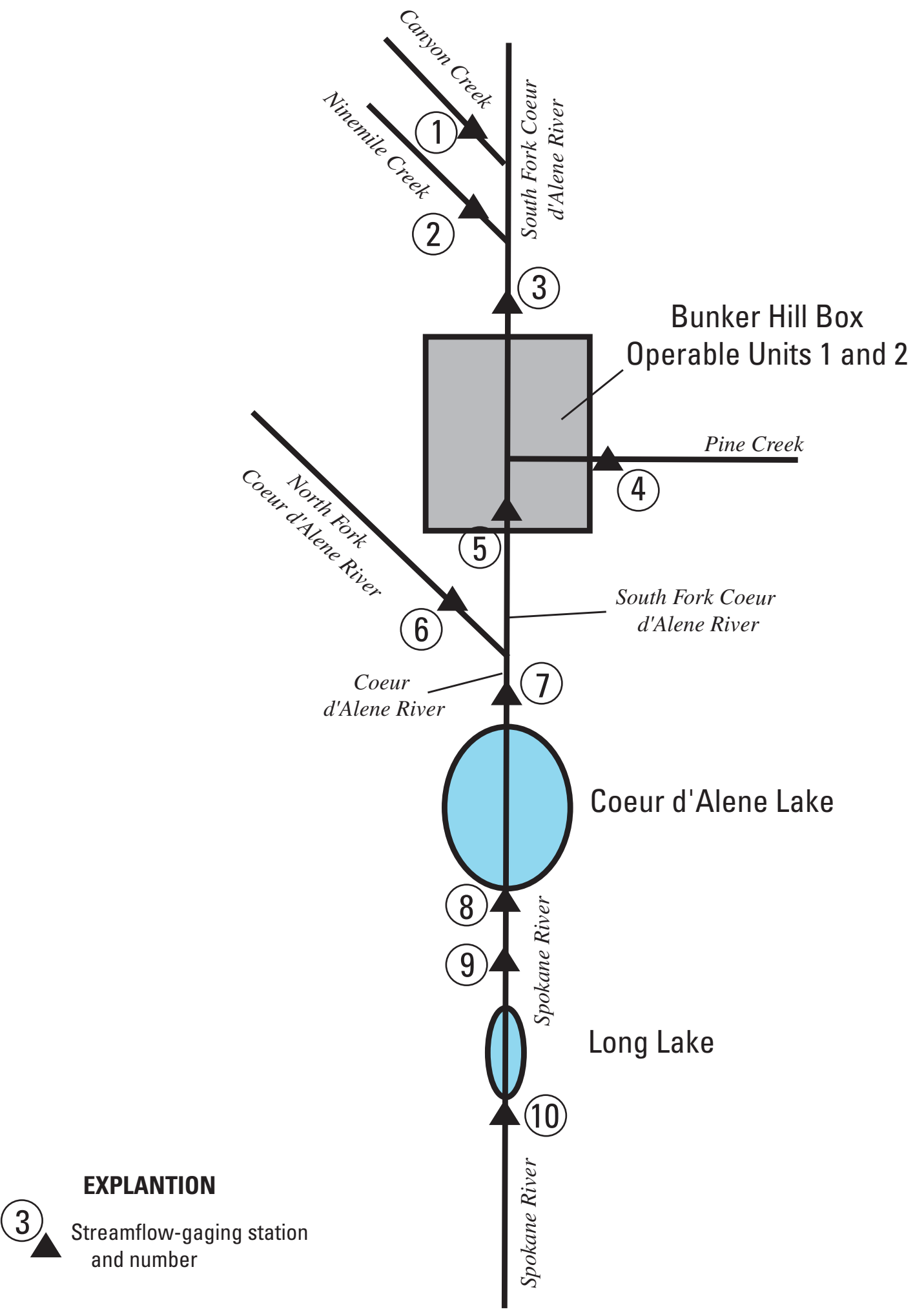

Figure 3. Relative locations and hydrologic relationships among 10 streamflow-gaging stations in the Spokane River basin, Idaho and Washington. Gaging station names are shown in table 1. 


\section{Method For Estimating Trace-Metal Loads}

Annual loads of dissolved and total cadmium (DCd and TCd), dissolved and total lead (DPb and TPb) and dissolved and total zinc (DZn and TZn) were estimated using the USGS software LOADEST, which uses instantaneous streamflow data and constituent concentrations to calibrate a regression model that describes constituent loads in terms of various functions of streamflow and time (Runkel and others, 2004). The software then uses the regression model to estimate loads over a user-specified interval for which daily mean streamflow data are provided. Model output includes statistical data to enable the user to evaluate the quality of the model. Model output also includes upper and lower 95-percent confidence interval (CI) for the entire estimation period to provide an understanding of the precision of the estimates. In this study, separate regression models were calibrated for each constituent for each of the 10 sampling sites. Daily loads were calculated and summed to obtain annual loads.

The software performs calibration procedures and makes load estimates using four statistical estimation methods: Adjusted Maximum Likelihood Estimation (AMLE), Maximum Likelihood Estimation (MLE), Linear Attribution Method (LAM), and Least Absolute Deviation (LAD). The user chooses the most appropriate method for the data being analyzed. AMLE and MLE are suitable when the model calibration errors (residuals) are normally distributed; AMLE is the more appropriate method of the two when the calibration data set contains censored data (for example, data that are reported as below or above some threshold). LAM and LAD are useful when the residuals are not normally distributed. The AMLE estimation method was selected because in many cases the calibration data sets included censored data. The initial model calibration residuals for each constituent were tested for normality by plotting the natural log of the residuals for the AMLE model against their Z-scores, both given in the LOADEST output file. These plots yielded generally straight lines, indicating that the residuals were normally distributed.

LOADEST software allows the user to choose between selecting the general form of the regression from among several predefined models and letting the software automatically choose the best model, based on the Akaike Information Criterion (Akaike, 1981). The selection criterion is designed to achieve a good balance between using as many predictor variables as possible to explain the variance in load while minimizing the standard error of the resulting estimates.
For this study, the software was allowed to choose the best model.

Output regression equations take the following general form:

$$
\begin{aligned}
\ln (L)= & a+b(\ln Q)+c\left(\ln Q^{2}\right)+d[\sin (2 \cdot T)] \\
& +e[\cos (2 \cdot T)]+f T+g T^{2}
\end{aligned}
$$

where

$L$ is constituent load, in $\mathrm{kg} / \mathrm{d}$;

$Q \quad$ is streamflow, in $\mathrm{ft}^{3} / \mathrm{s}$;

$T$ is time in decimal years from beginning of calibration period; and

$a, b, c, d, e, f$, and $g$ are regression coefficients.

Some regression equations in this study did not include all of the above terms, depending on the particular model chosen by the software. A complete discussion of the theory and principles behind calibration and estimation methods used by the LOADEST software is given by Runkel and others (2004).

\section{Model Input}

\section{Streamflow}

Streamflow at 9 of the 10 gaging stations in the sampling network was measured using standard USGS methods (Buchanan and Somers, 1968, 1969; Carter and Davidian, 1968), using a continuous record of water stage calibrated to periodic measurements. Station 7, however, is situated within the backwater created by Coeur d'Alene Lake and therefore does not have a valid stage-streamflow relation. To estimate streamflow at this station, the USGS streamflow model FourPt was used (Delong and others, 1997). The model uses channel geometry and water-stage data at upstream and downstream gaging stations in the stream reach being modeled. The model was calibrated using streamflow measurements over a wide range of streamflows and lake stage and was used to compute a daily mean streamflow for station 7 for WYs 1991-2004. Streamflow at station 8 was not available for WY 2003-04; therefore, streamflow for station 9 was used for 2003-04. 


\section{Trace-Metal Concentrations}

Short-term regression models were calibrated at 10 sites using trace-metal concentration data collected during 1999-2004. Long-term regression models also were calibrated for four of the sites using concentration data collected during 1991-2004. Trace-metal load estimates were compared for 1991-2004 based on two different regression models. This aspect of the study is discussed in the section "Estimated Trace-Metal Loads, 1999-2004"

The trace-metal concentration data used in this report were collected as part of a number of studies by the USGS. These studies included the Northern Rockies Intermontane Basins study of the National Water Quality Assessment program (NROK NAWQA) and the Remedial Investigation/ Feasibility Study (RI/FS) of the Spokane River basin (URSGreiner, 2001; Woods, 2001b; Clark and others, 2004). Because these studies had somewhat different objectives, the number of trace metal samples varied widely among the 10 sites (table 1). Nevertheless, all trace-metal concentration data were collected by USGS personnel and analyzed in USGS laboratory facilities using consistent methods and quality control measures.

The sampling approach for the NAWQA and RI/FS studies was to allocate samples over the full range of the station hydrograph to develop a robust relation between tracemetal concentration and streamflow. Generally, samples were collected on a fixed-interval frequency, and additional samples were collected during low or high streamflow. Additional samples were collected as part of the RI/FS study during significant streamflow events such as rain-on-snow, spring snowmelt runoff, and thunderstorms to characterize tracemetal transport during those times.

Samples at all stations were collected using nonmetallic samplers and cross-sectional, depth-integrated sampling procedures (Edwards and Glysson, 1988). Samples were composited and subsampled using a polyethylene churn or Teflon ${ }^{\circledR}$ cone-splitting device. Samples for whole-water recoverable (total) analyses were withdrawn directly from the splitting device. Samples for dissolved (smaller than $0.45-\mu \mathrm{m}$ diameter) analyses were withdrawn directly from either the churn splitter or a subsample of the cone splitter and passed through a pre-rinsed, 0.45 - $\mu \mathrm{m}$ pore size, disposable Gelman capsule filter. All trace-metal samples were preserved with $2 \mathrm{~mL}$ of Ultrex nitric acid. Samples were shipped in plastic coolers to the USGS National Water Quality Laboratory (NWQL) in Denver, Colo. About 10 percent of the samples were submitted as blanks, field spikes, and duplicates for quality assurance purposes as described by Friedman and Erdmann (1982) and Mueller and others (1997).
Samples at all stations were analyzed at the NWQL using similar analytical techniques. At the NWQL, samples were analyzed for total and dissolved concentrations of selected trace metals. Samples for total analysis were digested by heating with dilute hydrochloric acid and were filtered prior to analysis. Trace-metal concentrations were determined by atomic absorption spectrometry in conjunction with a graphite furnace and inductively coupled plasma-mass spectrometry (Fishman, 1993). Quality assurance/quality control procedures used at the NWQL were documented by Pritt and Raese (1995).

Trace-metal concentrations generally vary in relation to streamflow. For example, in samples collected during WYs 1999-2004 from the South Fork Coeur d'Alene River at Elizabeth Park, concentrations of TCd and TZn generally decreased and $\mathrm{TPb}$ increased with increasing streamflow (fig. 4). This relation between streamflow and concentration is typical of many mining-affected streams in the region (Clark, 2002).

Some samples having $\mathrm{Cd}$ concentrations near the minimum analytical detection limit were reported to have DCd concentration slightly higher than the TCd concentration, a situation that probably is an artifact of the analytical methods at low concentration. In most cases, the difference between DCd and TCd was less than 10 percent of the total concentration; therefore, the $\mathrm{Cd}$ in these samples was considered to be entirely dissolved.

\section{Regression Statistics}

Regression coefficients and coefficients of determination $\left(R^{2}\right)$ for the best-fit regression models for loads of dissolved and total $\mathrm{Cd}, \mathrm{Pb}$, and $\mathrm{Zn}$ for the 10 studied sites are presented in table 2. Coefficients of determination tended to be somewhat inflated because of the form of the regression equation. Because load is a function of flow (equation 1) a strong relation (high $\mathrm{R}^{2}$ ) is expected, unless large variations are in concentration. Nevertheless, the relatively high $R^{2}$ values indicate that, with few exceptions, the models for all constituents successfully simulated the variability in constituent loads at most sites.

Table 2 also shows $p$-values for coefficients of terms representing time as a variable in the regression equation (coefficient ' $f$ '). These coefficients can indicate trends in the load estimations. Because the 5-year interval for these estimates was considered insufficient to yield reliable trend results, they are not discussed here. However, trends for 14year load estimates are discussed later in the report. 


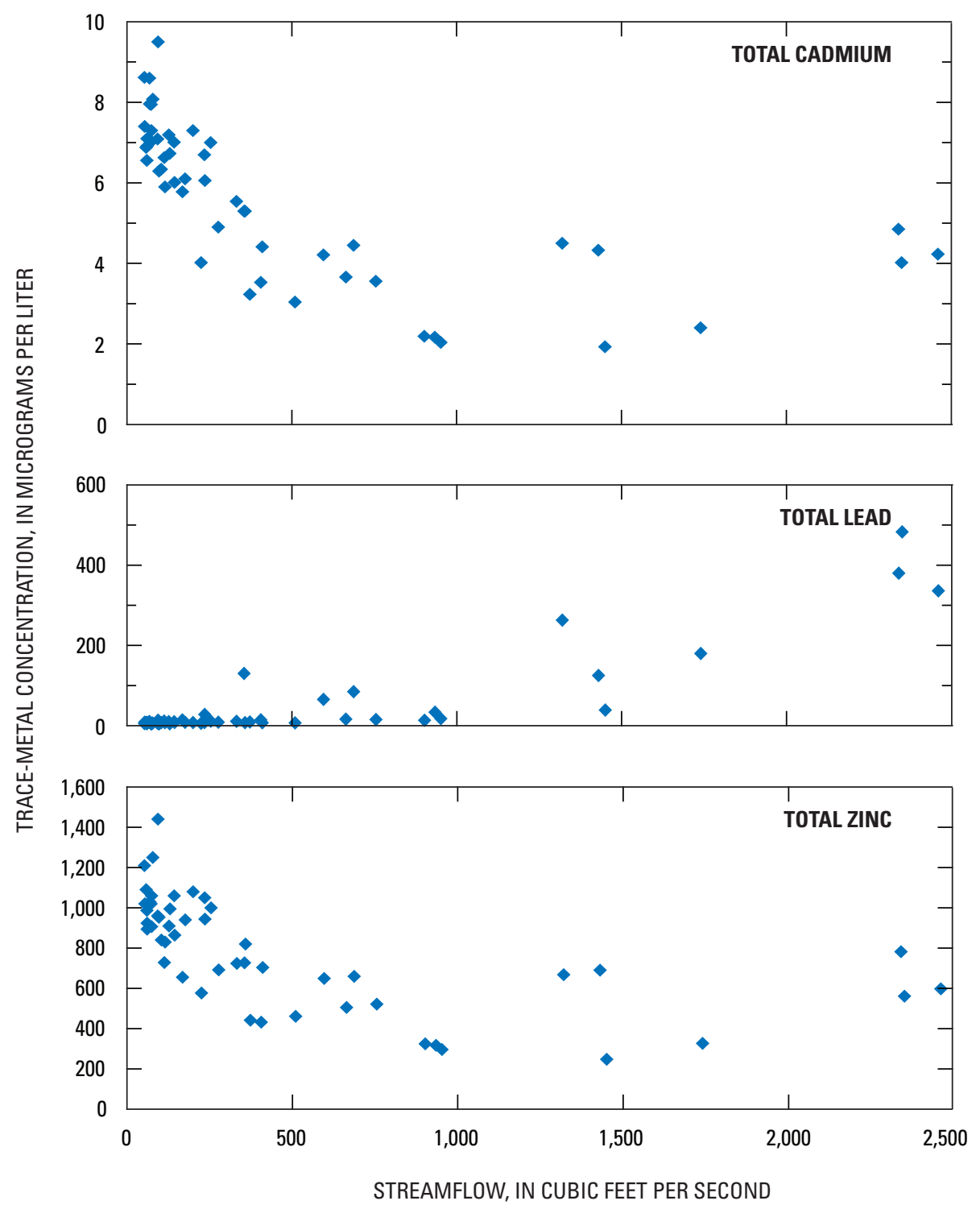

Figure 4. Relation between trace-metal concentrations and streamflow at U.S. Geological Survey streamflow-gaging station 12413210, South Fork Coeur d'Alene River at Elizabeth Park, near Kellogg, Idaho, water years 1999-2004. 
Table 2. Regression coefficients and coefficients of determination $\left(R^{2}\right)$ used to estimate dissolved and total cadmium, lead, and zinc loads at 10 streamflow-gaging stations in the Spokane River basin, Idaho and Washington, water years 1999-2004.

[Gaging station locations are shown in figures 1 and 2 . Regression equation is $\ln (L)=a+b(\ln Q)+c\left(\ln Q^{2}\right)+d[\sin (2 \bullet T)]+e[\cos (2 \bullet T)]+f T+g T^{2}$, where $L$ is constituent load; $Q$ is streamflow; $T$ is time in decimal years from beginning of calibration period; $a, b, c, d, e, f$, and $g$ are regression coefficients. Symbols: - , explanatory variable not used in regression; <, less than]

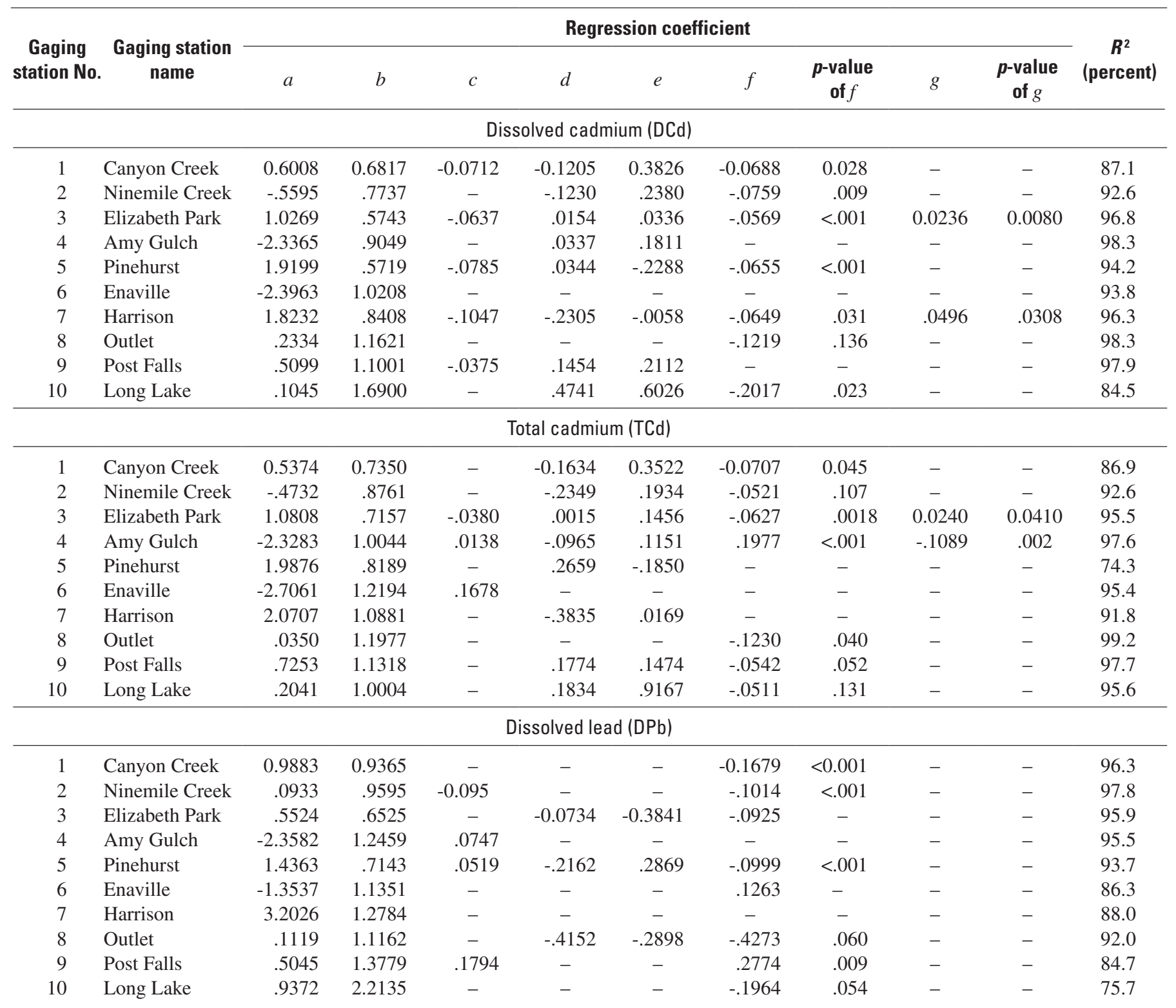


Table 2. Regression coefficients and coefficients of determination $\left(R^{2}\right)$ used to estimate dissolved and total cadmium, lead, and zinc loads at 10 streamflow-gaging stations in the Spokane River basin, Idaho and Washington, water years 1999-2004.-Continued

[Gaging station locations are shown in figures 1 and 2 . Regression equation is $\ln (L)=a+b(\ln Q)+c\left(\ln Q^{2}\right)+d[\sin (2 \bullet T)]+e[\cos (2 \bullet T)]+f T+g T^{2}$, where $L$ is constituent load; $Q$ is streamflow; $T$ is time in decimal years from beginning of calibration period; $a, b, c, d, e, f$, and $g$ are regression coefficients. Symbols: - , explanatory variable not used in regression; <, less than]

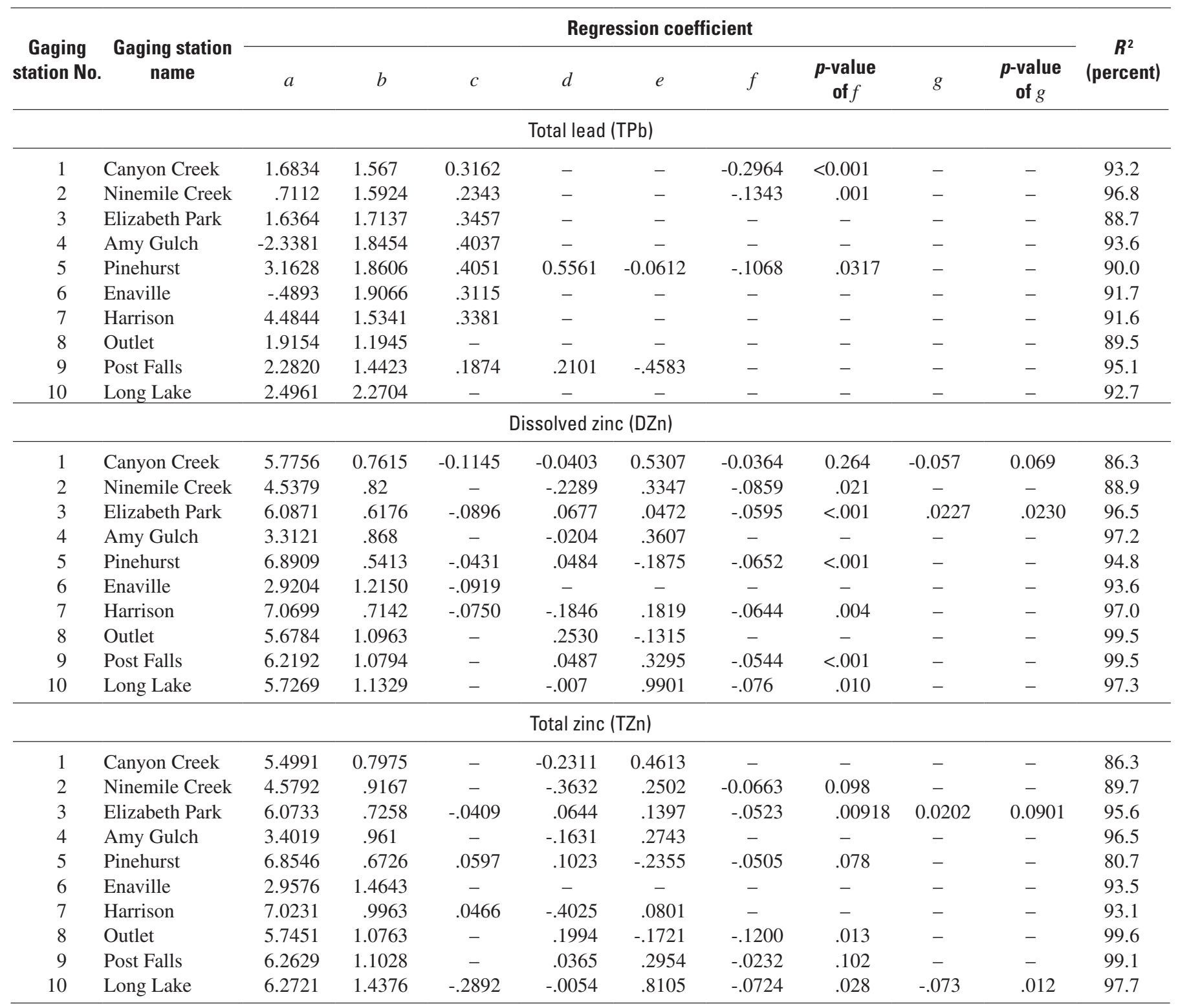




\section{Estimated Trace-Metal Loads, 1999-2004}

Estimated annual trace-metal loads of dissolved and total $\mathrm{Cd}, \mathrm{Pb}$, and $\mathrm{Zn}$ for 1999-2004 (referred to as "short-term" loads) for each site are presented in table 3. The overall mean total metal loads (the sum of TCd, TPb, and TZn) and the mean percentage of each metal of the sum are presented in table 3. Graphs showing mean streamflow and mean dissolved and total $\mathrm{Cd}, \mathrm{Pb}$, and $\mathrm{Zn}$ loads for each site for 1999-2004 are shown in figure 5.

\section{Cadmium Loads}

Estimated mean annual TCd loads were relatively low at Amy Gulch (39 kg/yr), Enaville (58 kg/yr), Ninemile Creek (200 kg/yr), and Canyon Creek (510 kg/yr). Conversely, estimated mean annual TCd loads were relatively high at Harrison (3,400 kg/yr), Pinehurst (2,600 kg/yr), Post Falls (1,500 kg/yr), and Elizabeth Park (1,200 kg/yr). The lowest single annual TCd load, $18 \mathrm{~kg}$, was estimated at Amy Gulch in 2001. Results for 2001, the lowest-flow year, marked the lowest TCd loads at every station in the basin.

The maximum annual TCd load, $5,100 \mathrm{~kg}$, was at Harrison in 1999. The same year also marked maximum loads at Pinehurst $(3,400 \mathrm{~kg})$, Post Falls $(2,100 \mathrm{~kg})$, and Elizabeth Park $(1,800 \mathrm{~kg}$ ) (table 3$)$. TCd loads for the entire estimation period were high at these four sites.

Dissolved Cd typically ranged from about 70 to 100 percent of the TCd load (fig. 5). In general, the $\mathrm{DCd} / \mathrm{TCd}$ ratio was higher at stations where ground water was a volumetrically important component of the streamflow, for example, on tributary streams farther upstream in the basin or at stations at the outlet of Coeur d'Alene Lake or Long Lake. DCd also is higher at most stations during low-flow years such as 2001, because of the greater contribution of ground water to streamflow. Relatively high $\mathrm{DCd} / \mathrm{TCd}$ ratios (about 0.9 and greater) were estimated at stations 1 through 4 . The lowest $\mathrm{DCd} / \mathrm{TCd}$ was estimated at Harrison, where less than 70 percent of the TCd was in the dissolved state.

In a few instances, DCd loads exceeded TCd loads because DCd concentrations were reported to be slightly higher than TCd concentrations when Cd levels were at or near the minimum analytical detection limit. Again, these situations indicate that essentially the entire $\mathrm{Cd}$ load is in the dissolved state.

\section{Lead Loads}

Stations 4 (Amy Gulch), 2 (Ninemile Creek), and 6 (Enaville) had relatively low mean annual estimated $\mathrm{TPb}$ loads: $1,700,2,100$, and 3,600 kg, respectively. The lowest single annual TPb load, $64 \mathrm{~kg}$, was at station 4 in 2001. Minimum TPb loads for 1999-2004 occurred mainly in 2001 at most stations, although 2003 also was characterized by low $\mathrm{TPb}$ loads.

The highest overall mean $\mathrm{TPb}$ loads in the basin were at Harrison (station 7). Mean annual TPb loads at Harrison exceeded those at all other stations by a factor of 6 or more. The maximum annual $\mathrm{TPb}$ load in the basin, about 590,000 $\mathrm{kg}$, was at Harrison for 2002. Water year 2002 also marked peak $\mathrm{TPb}$ loads at seven other stations in the basin, which may reflect flushing of accumulated $\mathrm{Pb}$-laden sediment that was stored in the stream channels during the previous year.

$\mathrm{The} \mathrm{DPb} / \mathrm{TPb}$ ratio varied in time and space and reflected the relative contribution of ground water (high in $\mathrm{DPb}$ ) to total streamflow and the presence (low $\mathrm{DPb} / \mathrm{TPb}$ ) or absence (high $\mathrm{DPb} / \mathrm{TPb}$ ) of $\mathrm{Pb}$-carrying suspended particulate and (or) colloidal material. $\mathrm{DPb} / \mathrm{TPb}$ ranged from less than 10 percent to nearly 30 percent of the $\mathrm{TPb}$ load. The highest $\mathrm{DPb} / \mathrm{TPb}$ loads were at stations 8, 9, and 10 (downstream of Coeur d'Alene Lake) and at stations 1 and 2, all stations where ground water contribution to streamflow is high and suspended sediment tends to be low under normal flow conditions.

\section{Zinc Loads}

Zinc is the primary constituent of metal loads in the Spokane River basin, composing more than 90 percent of the total metal load at 6 of the 10 stations. Relatively low mean annual TZn loads occurred at Amy Gulch (14,000 kg) and at Enaville $(17,000 \mathrm{~kg})$. The low loads at these two stations likely reflect the low availability of zinc in the source areas upstream of these stations.

Mean annual loads of TZn at Harrison were about $510,000 \mathrm{~kg} / \mathrm{yr}$ and far exceeded those at any other station. The single highest annual TZn load in the basin $(760,000 \mathrm{~kg})$ was at Harrison in 1999. High TZn loads also were measured at Pinehurst and Post Falls, with mean annual loads greater than $350,000 \mathrm{~kg}$. Mean annual loads of about 265,000 and 280,000 $\mathrm{kg}$ of TZn were estimated at the stations at Coeur d'Alene Lake outlet and Long Lake, respectively. 
Table 3. Estimated mean annual trace-metal loads for 10 streamflow-gaging stations in the Spokane River basin, Washington and Idaho, water years 1999-2004.

[Gaging station locations are shown in figures 1 and 2. All values in kilograms unless otherwise noted. Abbreviation: $\mathrm{m}^{3} / \mathrm{s}$, cubic meter per second. -, no estimate]

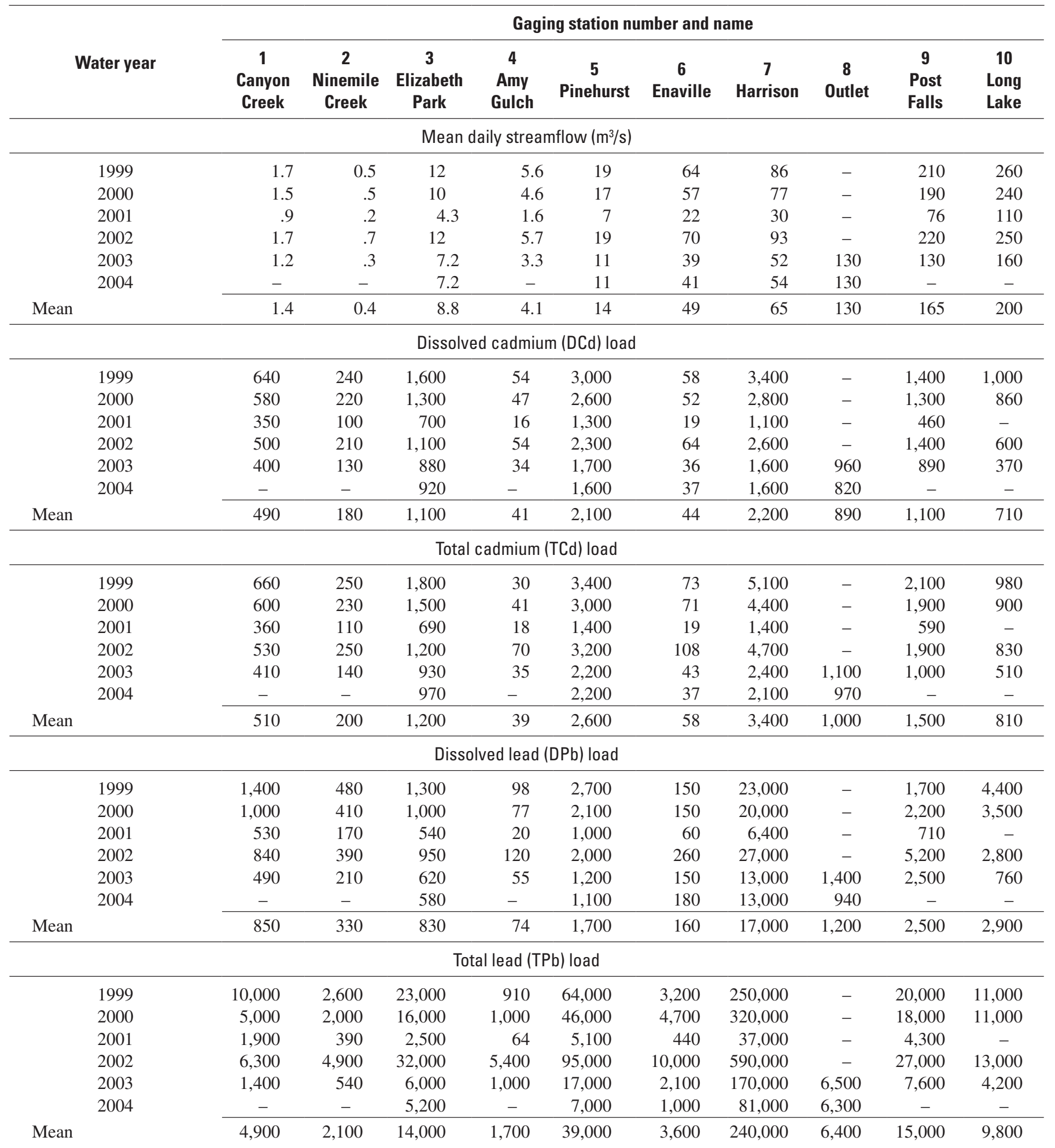


Table 3. Estimated mean annual trace-metal loads for 10 streamflow-gaging stations in the Spokane River basin, Washington and Idaho, water years 1999-2004.-Continued

[Gaging station locations are shown in figures 1 and 2. All values in kilograms unless otherwise noted. Abbreviation: $\mathrm{m}^{3} / \mathrm{s}$, cubic meter per second. -, no estimate]

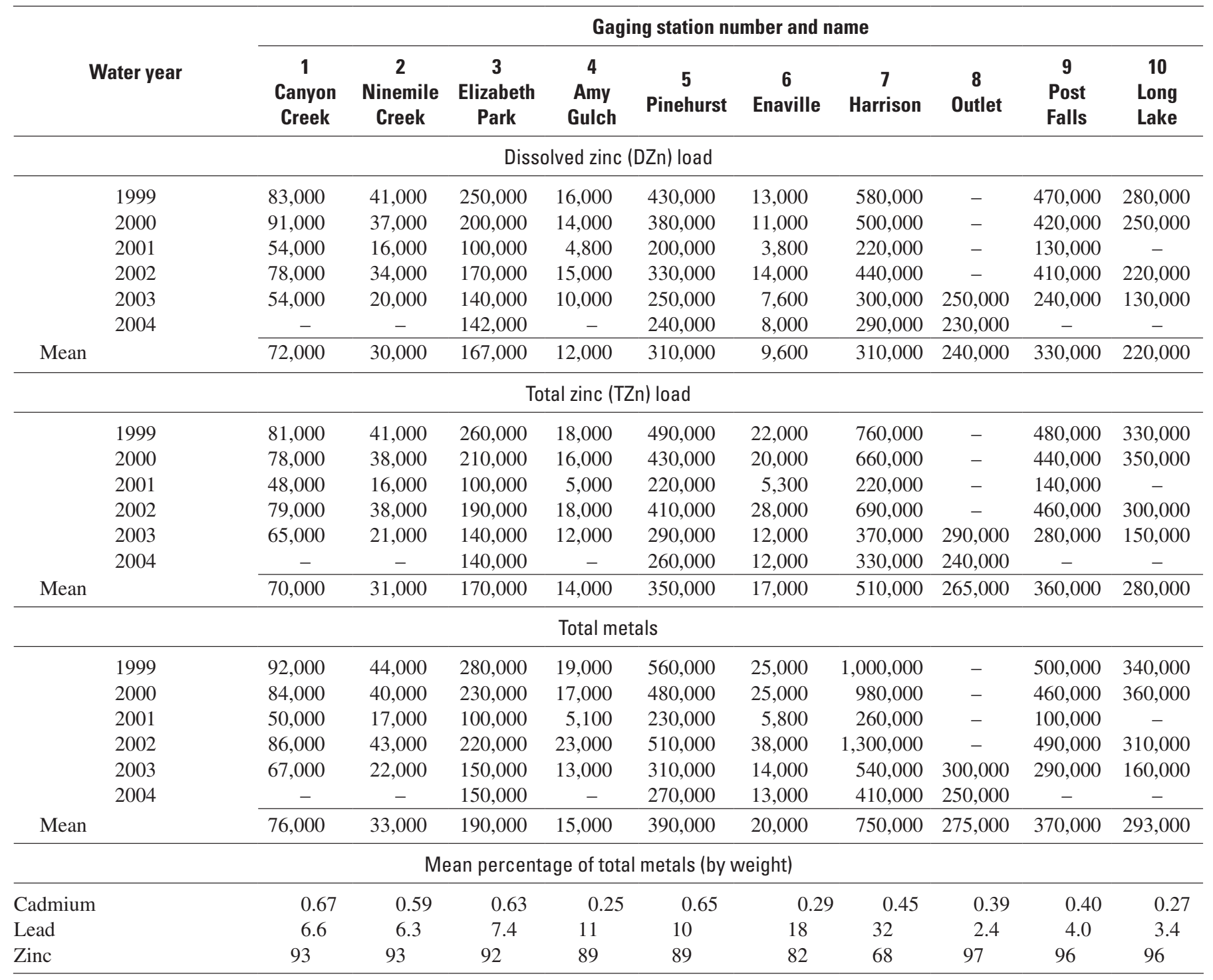



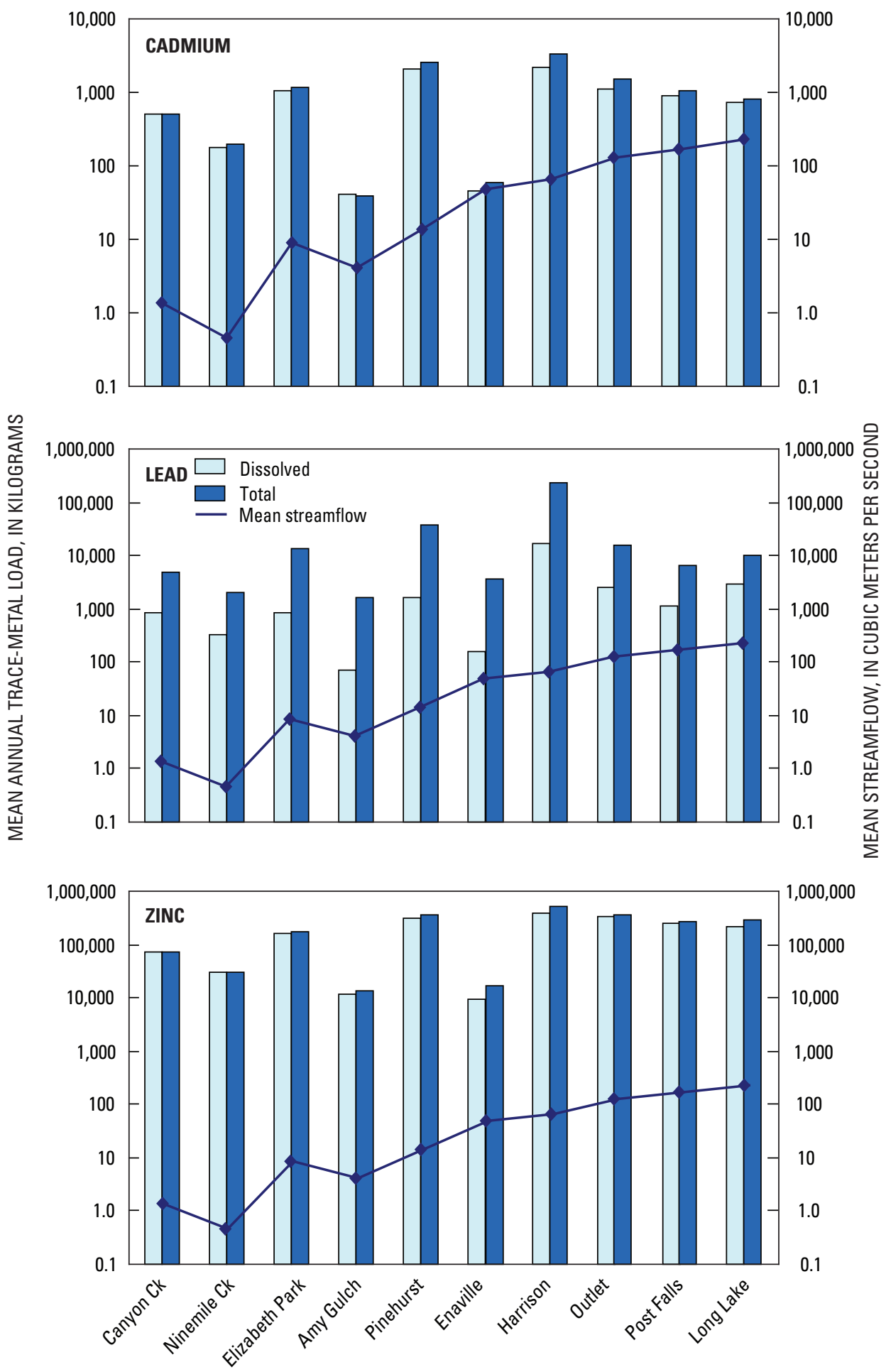

Figure 5. Mean annual estimated dissolved and total trace-metal loads and mean streamflow at 10 streamflow-gaging stations in the Spokane River basin, Idaho and Washington, water years 1999-2004. 
The DZn/TZn ratio typically was greater than 0.8 at most stations, indicating that zinc occurs primarily in the dissolved state. Although TZn loads were relatively low in 2001 due to low streamflow, the ratio DZn/TZn was higher in 2001 compared to other years resulting from high concentrations of $\mathrm{DZn}$ in ground water and less dilution of ground water inflow from snowmelt runoff.

\section{Spatial Patterns in Metal Loads and Proportions}

Mean total metal load (the sum of TCd, TPb, and TZn) for 1999-2004 ranged from about $15,000 \mathrm{~kg} / \mathrm{y}$ at station 4 to about $750,000 \mathrm{~kg} / \mathrm{y}$ at station 7 (table 3 ). The percentage of $\mathrm{Cd}$ of the total metal load at all stations was less than 1 percent. The percentage of $\mathrm{Pb}$ of the total metal load increased from about 6 percent at station 2 to about 32 percent downstream at station 7. Downstream of Coeur d'Alene Lake the percentage of $\mathrm{Pb}$ dropped to 2 to 4 percent at stations 8 through 10 . $\mathrm{Zn}$ accounted for the highest proportion of the total metal load at all stations. In contrast to $\mathrm{Pb}, \mathrm{Zn}$ regularly decreased from about 93 percent at stations 1 through 3 to about 68 percent at station 7. At stations 8 through 10, the proportion of $\mathrm{Zn}$ was the highest in the basin, about 96 percent.

Notable systematic differences between total metal loads at stations in different parts of the basin are partly due to the direct relation between streamflow and load. Generally, the further downstream the station's location in the Coeur d'Alene River basin, the higher the total metal load, because streamflow increases downstream. (Enaville is an exception; although it has relatively high mean streamflow, loads are relatively low because of low concentrations). Total metal loads at the three stations downstream of Coeur d'Alene Lake (stations 8, 9, and 10) are much less than metal loads at station 7. Only about 4,200 kg/y of metals enter Coeur d'Alene Lake from the St. Joe River via mean annual streamflow of about 2,900 $\mathrm{ft}^{3} / \mathrm{s}$ (Clark, 2002).

The decrease in metal loads at gaging stations downstream of Coeur d'Alene Lake likely is due to the well-documented process of retention of metals, particularly $\mathrm{Pb}$, in lakebed sediments (Horowitz and others, 1995; Clark, 2002). This study did not consider metals in the St. Joe River, but because $\mathrm{Pb}$ is primarily carried by particulate matter, a substantial amount of $\mathrm{Pb}$ is likely being deposited in the lakebed sediments. The relative proportions, as well as quantities, of metals upstream and downstream of the lake support this inference. The relative proportions of $\mathrm{Cd}, \mathrm{Pb}$, and $\mathrm{Zn}$ change notably upstream and downstream of the lake. For example, the percentage of $\mathrm{TPb}$ of the total metal load ranges from 6 percent at station 2 to 32 percent at station 7 . However, $\mathrm{TPb}$ is only 2-4 percent of the total metal load at stations 8 through 10.

Conversely, $\mathrm{Zn}$, which generally occurs in the dissolved state, accounts for a much higher proportion of the total metal load at stations $8-10$ than at station 7 . Indeed, the DZn/TZn load ratio rises sharply from 0.68 at stations 7 to 0.97 at station 8 . These data suggest that metals are affected by different storage and transport processes, and that water-quality data aid significantly in understanding these processes.

\section{Comparison with Previous Load Estimates}

Clark (2002) used LOADEST software to estimate loads for WY 1999-2001 at many of the same sites studied in this report. The input calibration data used by Clark were identical to the calibration data used in this study for 1999-2001, but these data also included data for 2002-04. Comparing Clark's results with those from this study is another opportunity to compare load estimates for the same time interval based on two different regressions.

Metal load estimates from this study for nine sites during 1999-2001 (produced by regressing data from 19992004) were compared with Clark's (2002) estimates for the same interval (table 4). Overall, there was fairly good agreement between the two sets of results. However, notable discrepancies, including $2001 \mathrm{TPb}$ results, were identified in estimates for Enaville. TPb annual load estimate from this study was higher than Clark's estimate by a factor of almost 2 . Smaller differences in TPb estimates for other years occurred at Harrison, Amy Gulch, and Elizabeth Park; most TPb discrepancies are negative, that is, estimates from this study were greater than Clark's estimates. One important difference between the two time intervals is that very low streamflow in 2001 strongly influenced Clark's results because that year's data constituted a greater proportion of the total available data, whereas, 2001 data were a smaller proportion of the available data for this study. Because the software uses the relation between flow and concentration to perform the regressions, including the subsequent 3 years' TPb and streamflow data probably resulted in a regression line with a steeper slope, causing estimated loads to be somewhat higher. In addition, this difference was probably more noticeable with $\mathrm{Pb}$ than with $\mathrm{Cd}$ or $\mathrm{Zn}$ because of the effect of streamflow on sediment transport and consequently, $\mathrm{Pb}$ load. 
Table 4. Comparison of trace-metal load estimates for water years 1999-2001 (this study) with estimates by Clark (2002) for nine streamflow-gaging stations in the Spokane River basin, Idaho and Washington.

[All values rounded, in kilograms. Abbreviation: na, not available]

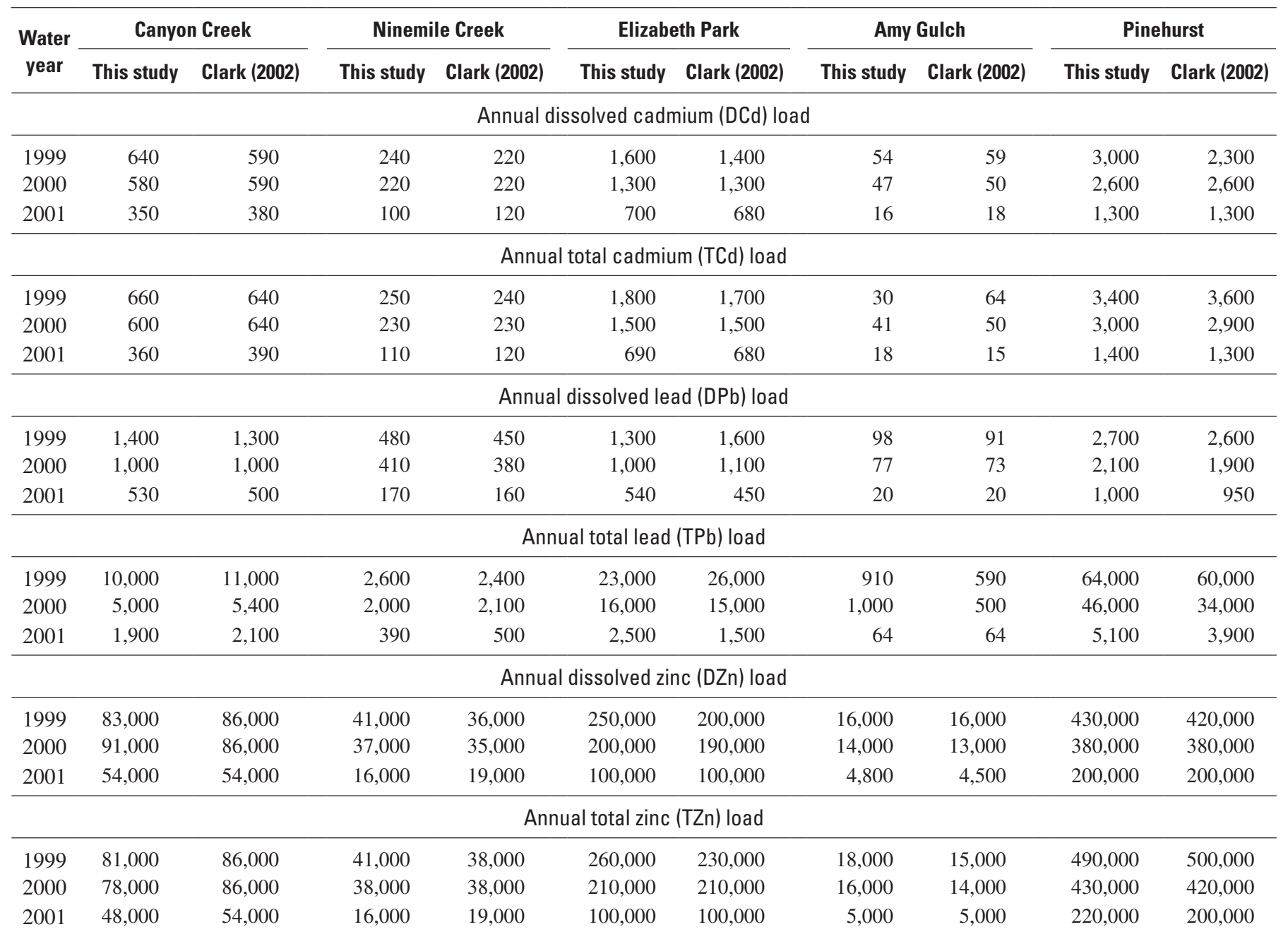


Table 4. Comparison of trace-metal load estimates for water years 1999-2001 (this study) with estimates by Clark (2002) for nine streamflow-gaging stations in the Spokane River basin, Idaho and Washington. - Continued

[All values rounded, in kilograms. Abbreviation: na, not available]

\begin{tabular}{|c|c|c|c|c|c|c|c|c|}
\hline \multirow{2}{*}{$\begin{array}{c}\text { Water } \\
\text { year }\end{array}$} & \multicolumn{2}{|c|}{ Enaville } & \multicolumn{2}{|c|}{ Harrison } & \multicolumn{2}{|c|}{ Post Falls } & \multicolumn{2}{|c|}{ Long Lake } \\
\hline & This study & Clark (2002) & This study & Clark (2002) & This study & Clark (2002) & This study & Clark (2002) \\
\hline \multicolumn{9}{|c|}{ Annual dissolved cadmium (DCd) load } \\
\hline 1999 & 58 & 73 & 3,400 & 3,500 & 1,400 & 1,800 & 1,000 & 950 \\
\hline 2000 & 52 & 64 & 2,800 & 2,800 & 1,300 & 1,500 & 860 & 950 \\
\hline 2001 & 19 & 25 & 1,100 & 1,000 & 460 & 450 & na & na \\
\hline \multicolumn{9}{|c|}{ Annual total cadmium (TCd) load } \\
\hline 1999 & 73 & 100 & 5,100 & 4,500 & 2,100 & 2,300 & 980 & 950 \\
\hline 2000 & 71 & 95 & 4,400 & 3,500 & 1,900 & 1,900 & 900 & 860 \\
\hline 2001 & 19 & 28 & 1,400 & 1,300 & 590 & 540 & na & na \\
\hline \multicolumn{9}{|c|}{ Annual dissolved lead (DPb) load } \\
\hline 1999 & 150 & 180 & 23,000 & 17,000 & 1,700 & 2,800 & 4,400 & 4,500 \\
\hline 2000 & 150 & 170 & 20,000 & 15,000 & 2,200 & 2,700 & 3,500 & 1,900 \\
\hline 2001 & 60 & 50 & 6,400 & 5,000 & 710 & 590 & na & na \\
\hline \multicolumn{9}{|c|}{ Annual total lead (TPb) load } \\
\hline 1999 & 3,200 & 2,900 & 250,000 & 210,000 & 20,000 & 21,000 & 11,000 & 11,000 \\
\hline 2000 & 4,700 & 4,500 & 320,000 & 240,000 & 18,000 & 19,000 & 11,000 & 10,000 \\
\hline 2001 & 440 & 160 & 37,000 & 40,000 & 4,300 & 4,000 & na & na \\
\hline \multicolumn{9}{|c|}{ Annual dissolved zinc (DZn) load } \\
\hline 1999 & 13,000 & 10,000 & 580,000 & 540,000 & 470,000 & 450,000 & 280,000 & 270,000 \\
\hline 2000 & 11,000 & 9,100 & 500,000 & 450,000 & 420,000 & 400,000 & 250,000 & 260,000 \\
\hline 2001 & 3,800 & 3,100 & 220,000 & 210,000 & 130,000 & 130,000 & na & na \\
\hline \multicolumn{9}{|c|}{ Annual total zinc (TZn) load } \\
\hline 1999 & 22,000 & 22,000 & 760,000 & 680,000 & 480,000 & 450,000 & 330,000 & 340,000 \\
\hline 2000 & 20,000 & 20,000 & 660,000 & 540,000 & 440,000 & 440,000 & 350,000 & 330,000 \\
\hline 2001 & 5,300 & 5,300 & 220,000 & 220,000 & 140,000 & 150,000 & na & na \\
\hline
\end{tabular}




\section{Flow-Weighted Concentrations of Trace Metals, 1999-2004}

Constituent loads are calculated as the product of streamflow and concentration. Because load calculation results are strongly governed by variations in streamflow, a calculated load may not be the best measure by which to analyze metal transport and behavior. Interpretation of calculated annual loads is improved by examining mean annual Flow-Weighted Concentrations (FWCs) of trace metals. A FWC is an estimate of the mean actual concentration in a total volume of water flowing past a site in a specific period, such as a month or year.

FWCs permit a better understanding of metal transport in the context of variable streamflow conditions and relative location in the basin. For example, table 5 shows mean daily streamflow from 1999 to 2004 ranged from less than $1 \mathrm{~m}^{3} / \mathrm{s}$ at Ninemile Creek to greater than $200 \mathrm{~m}^{3} / \mathrm{s}$ at Long Lake. Mean annual streamflow at Amy Gulch varied by more than a factor of 3 during this period. By examining FWCs, a better understanding of the true differences in metal transport can be gained.

Mean annual FWCs for total and dissolved $\mathrm{Cd}, \mathrm{Pb}$, and $\mathrm{Zn}$ are presented in table 5; the overall mean FWCs for the 10 sites are presented in figure 6. Mean annual FWCs were calculated by the following method. Daily load estimates for each constituent, in kilograms, were summed to obtain annual total loads for each year. Annual sums were divided by the total streamflow, in cubic meters, for that year. Appropriate conversion factors were applied to obtain mean annual FWCs in micrograms per liter.

Total Cd FWCs in the Coeur d'Alene basin ranged from 14 to $0.04 \mu \mathrm{g} / \mathrm{L}$. Concentrations were highest at Ninemile Creek and Canyon Creek, where estimated loads were relatively low due to low mean streamflow. TCd FWCs were lowest at Enaville; TCd loads also were low at this station, indicating overall low metal contribution from the North
Fork Coeur d'Alene River. Low TCd FWCs were measured at stations downstream from Coeur d'Alene Lake, even though TCd loads at these sites were relatively high. This demonstrates that although concentrations may be low because of high streamflow, the overall transport of trace metals can be high.

Total $\mathrm{Pb}$ FWCs were highest at Ninemile Creek, Canyon Creek, and Harrison. Elevated TPb FWCs at Harrison confirmed that the high $\mathrm{TPb}$ loads at this station were not simply due to higher streamflow; downstream dilution did not compensate for additional sources of metal. Conversely, relatively low $\mathrm{TPb}$ loads together with high $\mathrm{TPb}$ FWCs at Ninemile and Canyon Creeks reflect low streamflow but high concentrations of $\mathrm{TPb}$.

Total zinc FWCs also demonstrated the profound effect of streamflow on load calculations, and indicated source areas for zinc in the basin. Total Zn FWCs at Ninemile and Canyon Creeks are by far the highest in the basin but contribute among the lowest TZn loads due to their relatively low streamflow. Conversely, stations downstream from Coeur d'Alene Lake exhibit among the lowest TZn FWCs, but TZn load estimates are high because of their high mean streamflow relative to other stations in the basin.

Effects of dilution were recognized by examining TZn loads together with FWCs at Pinehurst and Harrison. Mean annual flows at Pinehurst generally were about 20 percent of those at Harrison. Although mean annual TZn loads at Pinehurst were slightly less than loads at Harrison, the mean annual FWCs of TZn at Pinehurst were more than 3 times greater than FWCs at Harrison, due to downstream dilution of metals by inflow of the North Fork Coeur d'Alene River just downstream of Pinehurst (fig. 6).

Total metal loads and FWCs at Enaville are among the lowest in the basin. This likely reflects an upstream source area low in metals in addition to the effects of dilution by relatively high streamflow at this site. Overall, these data confirm the low metal contribution of this part of the basin to the whole. 
Table 5. Estimated mean annual flow-weighted concentrations of trace metals for 10 streamflow-gaging stations in the Spokane River basin, Idaho and Washington, water years 1999-2004.

[Gaging station locations are shown in figures 1 and 2. All values are in micrograms per liter unless otherwise noted. Abbreviations: FWC, flow-weighted concentration; $\mathrm{m}^{3} / \mathrm{s}$, cubic meter per second. Symbols: - , no estimate]

\begin{tabular}{|c|c|c|c|c|c|c|c|c|c|c|}
\hline $\begin{array}{c}\text { Water } \\
\text { year }\end{array}$ & \multicolumn{10}{|c|}{ Gaging station number and name } \\
\hline \multicolumn{11}{|c|}{ Mean annual streamflow $\left(\mathrm{m}^{3} / \mathrm{s}\right)$} \\
\hline 1999 & 1.7 & 0.5 & 12 & 5.6 & 19 & 64 & 86 & - & 210 & 260 \\
\hline 2002 & 1.7 & .7 & 12 & 5.7 & 19 & 70 & 93 & - & 220 & 250 \\
\hline 2003 & 1.2 & .3 & 7.2 & 3.3 & 11 & 39 & 52 & 130 & 130 & 160 \\
\hline 2004 & - & - & 7.2 & - & 11 & 41 & 54 & 130 & - & - \\
\hline Mean & 1.4 & 0.5 & 8.8 & 4.1 & 14 & 49 & 65 & 130 & 165 & 200 \\
\hline 2002 & 9.1 & 9.8 & 2.9 & .30 & 3.7 & .03 & .87 & - & .21 & .08 \\
\hline 2003 & 11 & 12 & 3.8 & .33 & 4.9 & .03 & .97 & 0.23 & .21 & .07 \\
\hline 2004 & - & - & 4.1 & - & 4.6 & .03 & .92 & .20 & - & - \\
\hline Mean & 11 & 13 & 4.0 & 0.32 & 4.9 & 0.03 & 1.1 & 0.21 & 0.21 & 0.10 \\
\hline \multicolumn{11}{|c|}{ Total cadmium (TCd) FWC } \\
\hline 1999 & 12 & 15 & 4.9 & 0.17 & 5.5 & 0.04 & 1.9 & - & 0.31 & 0.12 \\
\hline 2000 & 13 & 15 & 4.5 & .28 & 5.8 & .04 & 1.8 & - & .30 & .12 \\
\hline 2001 & 13 & 15 & 5.1 & .36 & 6.6 & .03 & 1.4 & - & .25 & - \\
\hline 2002 & 9.6 & 11 & 3.3 & .39 & 5.2 & .05 & 1.6 & - & .27 & .10 \\
\hline 2001 & 19 & 24 & 4.0 & .41 & 5.0 & .09 & 6.7 & - & .29 & - \\
\hline 2002 & 15 & 18 & 2.5 & .65 & 3.3 & .12 & 9.0 & - & .74 & .35 \\
\hline 2003 & 13 & 20 & 2.7 & .53 & 3.3 & .12 & 7.7 & 0.33 & .61 & .15 \\
\hline 2004 & - & - & 2.6 & - & 3.1 & .14 & 7.4 & .23 & - & - \\
\hline Mean & 19 & 23 & 3.1 & 0.53 & 3.9 & 0.10 & 7.9 & 0.28 & 0.45 & 0.37 \\
\hline
\end{tabular}


Table 5. Estimated mean annual flow-weighted concentrations of trace metals for 10 streamflow-gaging stations in the Spokane River basin, Idaho and Washington, water years 1999-2004.-Continued

[Gaging station locations are shown in figures 1 and $\underline{2}$. All values are in micrograms per liter unless otherwise noted. Abbreviations: FWC, flow-weighted concentration; $\mathrm{m}^{3} / \mathrm{s}$, cubic meter per second. Symbols: -, no estimate]

\begin{tabular}{|c|c|c|c|c|c|c|c|c|c|c|}
\hline $\begin{array}{c}\text { Water } \\
\text { year }\end{array}$ & \multicolumn{10}{|c|}{ Gaging station number and name } \\
\hline \multicolumn{11}{|c|}{ Total lead (TPb) FWC } \\
\hline 1999 & 190 & 150 & 61 & 5.2 & 100 & 1.6 & 91 & - & 2.9 & 1.3 \\
\hline 2002 & 110 & 230 & 84 & 30 & 160 & 4.5 & 200 & - & 3.9 & 1.7 \\
\hline 2003 & 38 & 51 & 26 & 9.8 & 48 & 1.7 & 100 & 1.5 & 1.8 & .8 \\
\hline 2004 & - & - & 23 & - & 20 & .77 & 48 & 1.5 & - & - \\
\hline Mean & 100 & 120 & 43 & 11 & 73 & 2.0 & 100 & 1.5 & 2.7 & 1.3 \\
\hline 2002 & 1,400 & 1,600 & 400 & 85 & 550 & 6.2 & 150 & - & 58 & 27 \\
\hline 2003 & 1,500 & 1,900 & 600 & 100 & 710 & 6.1 & 180 & 61 & 58 & 26 \\
\hline 2004 & - & - & 630 & - & 680 & 6.2 & 170 & 57 & - & - \\
\hline Mean & 1,700 & 2,100 & 610 & 93 & 720 & 6.1 & 190 & 59 & 62 & 30 \\
\hline \multicolumn{11}{|c|}{ Total zinc (TZn) } \\
\hline 1999 & 1,500 & 2,400 & 700 & 100 & 800 & 11 & 280 & - & 71 & 40 \\
\hline 2000 & 1,700 & 2,400 & 650 & 110 & 820 & 11 & 270 & - & 71 & 46 \\
\hline 2001 & 1,700 & 2,200 & 740 & 100 & 1,000 & 7.8 & 230 & - & 60 & - \\
\hline 2002 & 1,400 & 1,800 & 490 & 100 & 670 & 13 & 230 & - & 67 & 38 \\
\hline
\end{tabular}




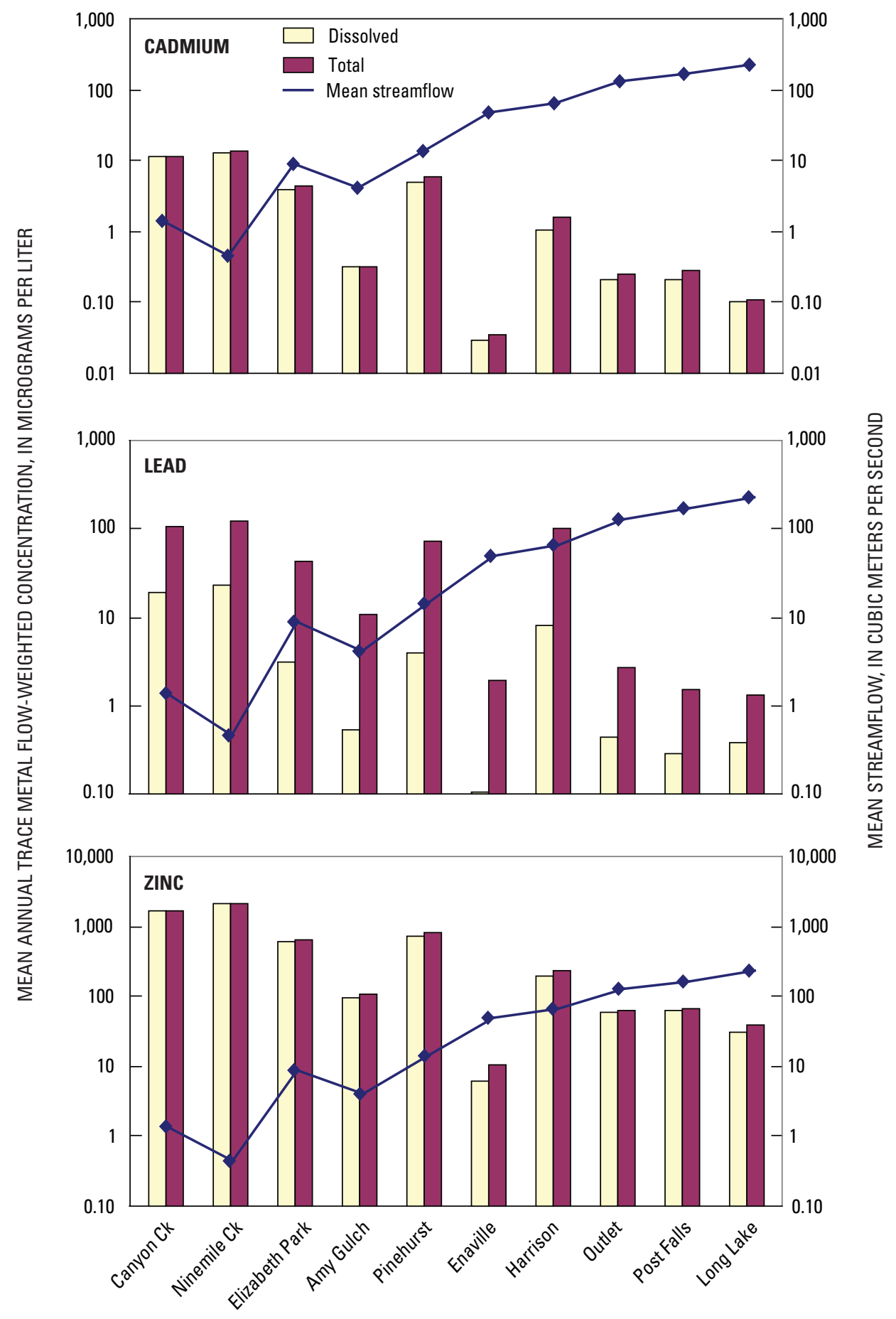

Figure 6. Mean annual flow-weighted concentrations of trace metals and mean streamflow at 10 streamflow-gaging stations in the Spokane River basin, Idaho and Washington, water years 1999-2004. 


\section{Estimated Trace-Metal Loads and Flow-Weighted Concentrations, 1991-2004}

Regression models were developed and annual tracemetal loads and FWCs were estimated for Enaville (19922004), Pinehurst, Harrison, (1991-2004) and Post Falls (19912003) to understand the variability of metal loading with time. Because these load models and estimates cover a longer interval than the 1999-2004 study, they are described as "longterm." Developing long-term regression models for these four sites also enabled a comparison of the load estimates produced for 1991-2004 with those for 1999-2004 and an examination of the robustness of the two differently calibrated models, specifically for the latter period. The metal concentration data for 1999-2004 were the same as those used for the short-term load simulation. The regression coefficients and coefficients of determination $\left(R^{2}\right)$ of the long-term models are presented in table 6. Long-term annual load estimates and FWCs are summarized in table 7. Graphs of annual estimated loads at all sites for all years are shown in figure 6. The graphs in figure 7 summarize the long-term mean annual metal loads for the four stations. The mean annual flow-weighted concentrations calculated from the long-term loads are shown in figure 8 .

Long-term load estimates are similar to the results for 1999-2004 in terms of mean annual metal loads. For example, the largest mean loads for the estimation period were measured at Harrison and Pinehurst. Generally, the highest estimated loads were in 1996 and 1997 at all four stations, primarily because of extremely high flows. High loads also were measured in 1991. The lowest loads prior to 1999 generally were in lower-flow years, 1994 and 1998. Although low estimated loads in 1994 and 1998 probably reflect low streamflow, estimated loads in 1998 also may reflect a lack of sufficient time for metals to accumulate upstream after unusually high flows in 1996 and 1997 had scoured the channels.

\section{Comparison with 1999-2004 Estimates}

Long-term trace-metal load estimates for 1999-2004 generally compare well with the estimates produced by the short-term model for the overlapping time interval, but the similarity of the estimates varies from station to station, from year to year, and from metal to metal (table 8, fig. 9). The most consistent results for a single station were obtained from the gaging station at Pinehurst, where the long-term results for all metals are within 10 percent of the short-term estimates, except the TCd estimate for 2004. The estimated TZn load at Pinehurst is within 1 percent of the short-term estimates for all six years. Large differences in TCd load estimates were computed at Enaville in 1999 and in TPb estimates at Enaville, Harrison, and Post Falls for a number of years.

Because the load regression is based on the log-linear relation between flow and concentration, if the calibration data files represent a different range of flow or concentration values, the resulting regression may yield different load estimates due to the differences in regression line slopes. This is exemplified by the data for Pinehurst. The shortterm load estimates for $\mathrm{DPb}$ are 17 to 54 percent lower than the long-term estimates. Comparison of the two calibration files shows the likely reason: the mean concentrations for most metals were in good agreement, except that the mean $\mathrm{DPb}$ concentration of the short-term calibration data was about 50 percent lower than that of the long-term data. This demonstrates the importance of assuring that input data adequately represent conditions during the time interval for which loads are estimated. Results should not be extrapolated beyond the time interval or flow regime represented by the input data.

Because the calibration data used in the long-term regressions and the short-term regressions were the same for 1999-2004, differences in the estimated loads for that period result from the differences in the regression equations produced by the model in the two cases. For example, the short- and long-term estimates for 2001 were similar at all four stations; the differences never exceeded 10 percent for any metal. This may be related to low streamflow (and consequently, load estimates) in 2001, the lowest in the 14-year estimation interval, a year that was common to both short- and long-term regressions. Conversely, the highest-flow years in the 14-year interval were 1996 and 1997, years that were not included in the short-term model regressions. The two models probably treat low-flow conditions similarly, but provide different results for high-flow conditions because calibration data for the long-term model provided data for lowand high-flow years, whereas data for the short-term model did not.

The value of long-term versus short-term load estimates ultimately depends on data available, questions being addressed, and purposes for which the results will be used. In this study, longer estimation intervals gave a more complete account of metal loading in the basin at the four long-term stations. Nevertheless, the most vital criterion to achieve the best results using LOADEST is that the calibration data be representative of the conditions, both hydrologic and temporal, during the simulated interval. 
Table 6. Regression coefficients and coefficients of determination $\left(R^{2}\right)$ for load models used to estimate dissolved and total cadmium, lead, and zinc loads at four streamflow-gaging stations in the Spokane River basin, Idaho.

[Gaging station locations are shown in figures 1 and 2. Long-term records are for the periods: Enaville (1992-2004), Pinehurst, Harrison (1991-2004), and Post Falls (1991-2003). Regression equation is $\ln (L)=a+b(\ln Q)+c\left(\ln Q^{2}\right)+d[\sin (2 \bullet T)]+e[\cos (2 \bullet T)]+f T+g T^{2}$, where $L$ is constituent load; $Q$ is streamflow; $T$ is time in decimal years from beginning of calibration period; $a, b, c, d, e, f$, and $g$ are regression coefficients. Symbols: -, explanatory variable not used in regression; <, less than]

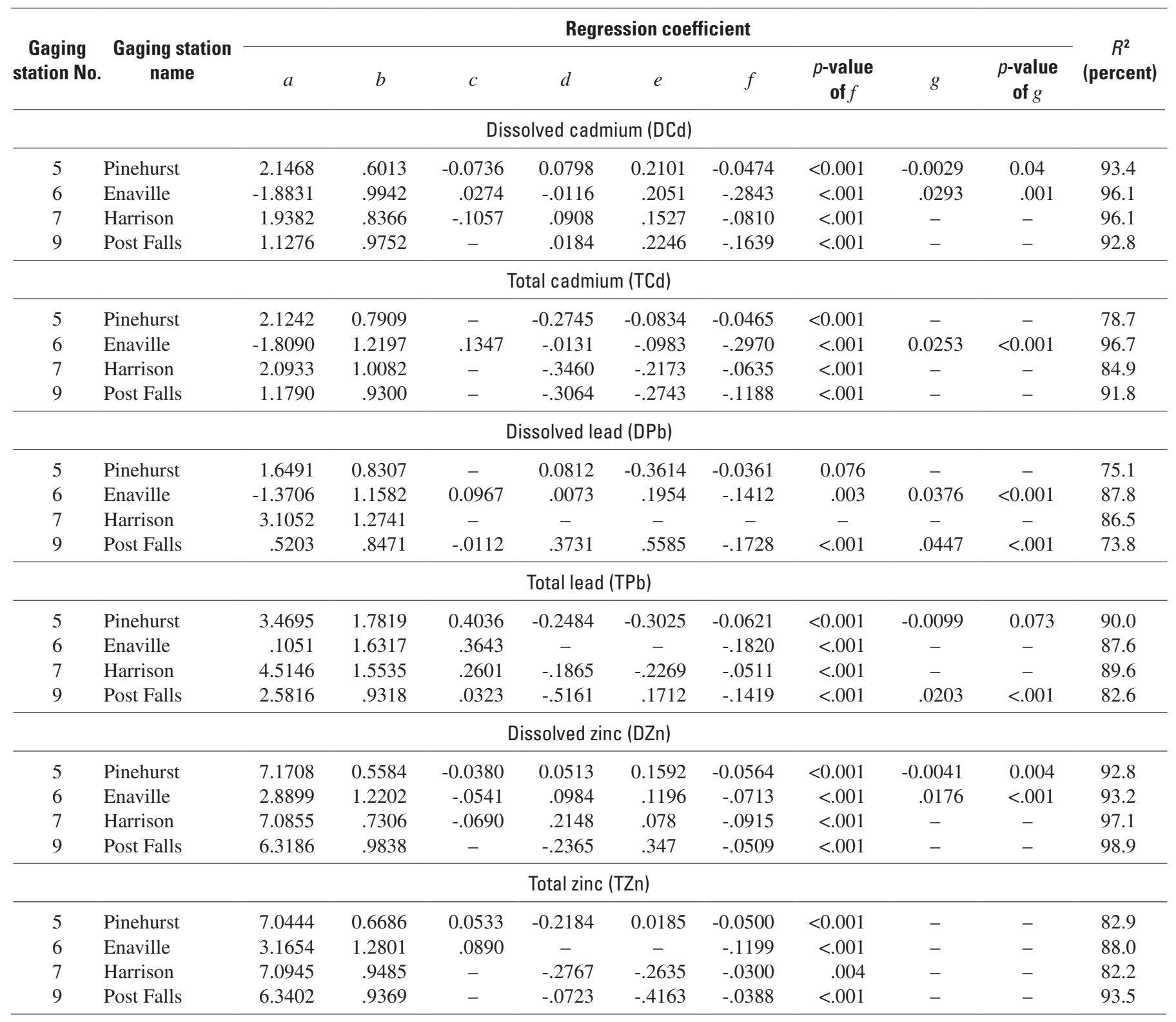


Table 7. Estimated long-term mean annual trace-metal loads and flow-weighted concentrations of cadmium, lead, and zinc at four streamflow-gaging stations in the Spokane River basin, Idaho.

[Long-term records are for the periods: Enaville (1992-2004), Pinehurst, Harrison (1991-2004), and Post Falls (1991-2003). Abbreviations: $\mathrm{m}^{3} / \mathrm{s}, \mathrm{cubic}^{\mathrm{meter}}$ per second; $\mu \mathrm{g} / \mathrm{L}$, microgram per liter. -, no estimate]

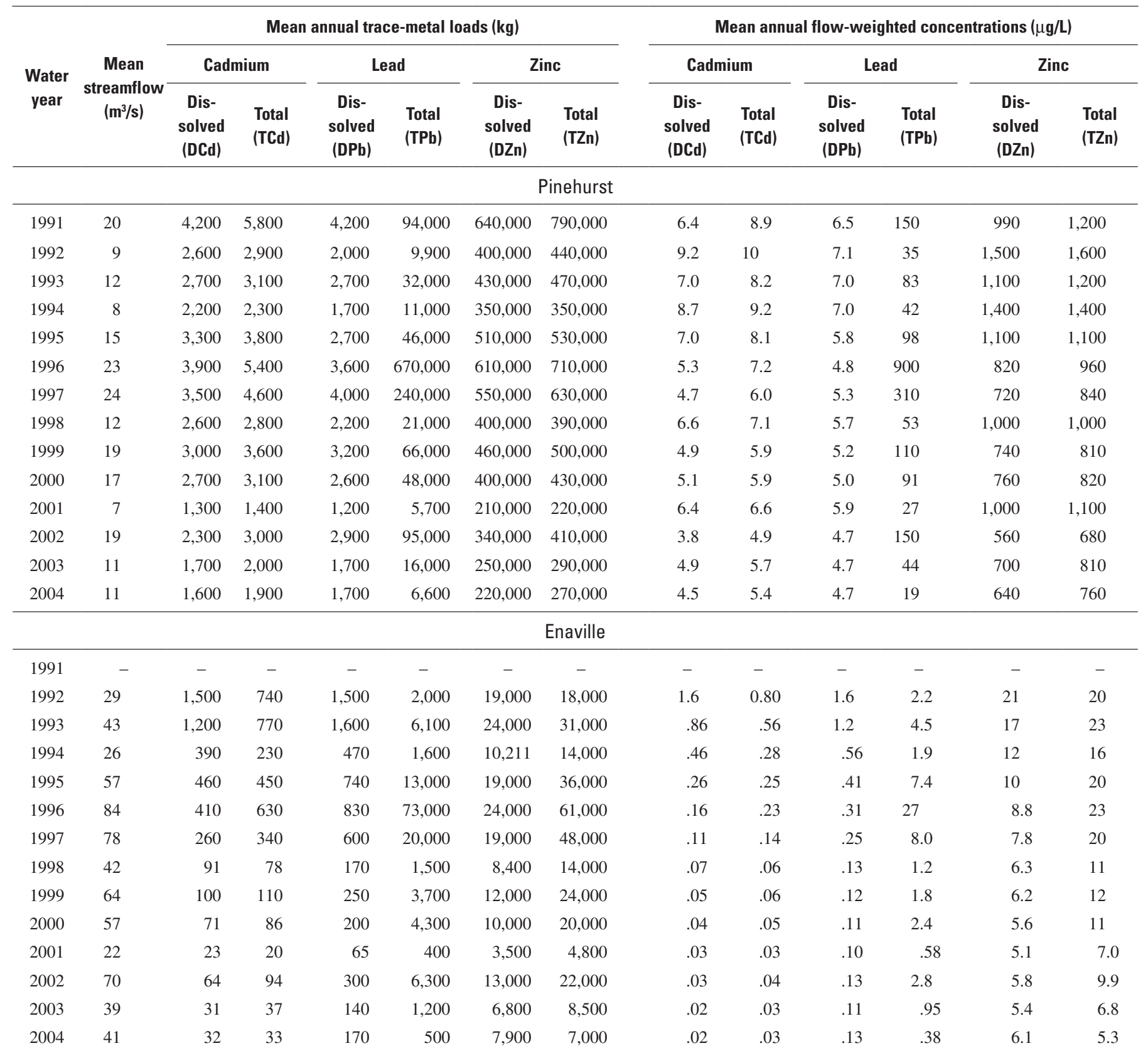


Table 7. Estimated long-term mean annual trace-metal loads and flow-weighted concentrations of cadmium, lead, and zinc at four streamflow-gaging stations in the Spokane River basin, Idaho.-Continued

[Long-term records are for the periods: Enaville (1992-2004), Pinehurst, Harrison (1991-2004), and Post Falls (1991-2003). Abbreviations: m³/s, cubic meter per second; $\mu \mathrm{g} / \mathrm{L}$, microgram per liter. -, no estimate]

\begin{tabular}{|c|c|c|c|c|c|c|c|c|c|c|c|c|c|}
\hline \multirow{2}{*}{$\begin{array}{c}\text { Water } \\
\text { year }\end{array}$} & \multirow{2}{*}{$\begin{array}{c}\text { Mean } \\
\text { streamflow } \\
\left(\mathrm{m}^{3} / \mathrm{s}\right)\end{array}$} & \multicolumn{6}{|c|}{ Mean annual trace-metal loads $(\mathrm{kg})$} & \multicolumn{6}{|c|}{ Mean annual flow-weighted concentrations $(\mu \mathrm{g} / \mathrm{L})$} \\
\hline & & $\begin{array}{c}\text { Dis- } \\
\text { solved } \\
\text { (DCd) }\end{array}$ & $\begin{array}{l}\text { Total } \\
\text { (TCd) }\end{array}$ & $\begin{array}{c}\text { Dis- } \\
\text { solved } \\
(\mathrm{DPb})\end{array}$ & $\begin{array}{l}\text { Total } \\
\text { (TPb) }\end{array}$ & $\begin{array}{c}\text { Dis- } \\
\text { solved } \\
\text { (DZn) }\end{array}$ & $\begin{array}{l}\text { Total } \\
\text { (TZn) }\end{array}$ & $\begin{array}{c}\text { Dis- } \\
\text { solved } \\
\text { (DCd) }\end{array}$ & $\begin{array}{l}\text { Total } \\
\text { (TCd) }\end{array}$ & $\begin{array}{c}\text { Dis- } \\
\text { solved } \\
\text { (DPb) }\end{array}$ & $\begin{array}{l}\text { Total } \\
\text { (TPb) }\end{array}$ & $\begin{array}{c}\text { Dis- } \\
\text { solved } \\
\text { (DZn) }\end{array}$ & $\begin{array}{l}\text { Total } \\
\text { (TZn) }\end{array}$ \\
\hline \multicolumn{14}{|c|}{ Harrison } \\
\hline 1992 & 42 & 3,700 & 4,200 & 8,900 & 71,000 & 750,000 & 510,000 & 1.2 & 1.4 & 2.9 & 23 & 250 & 170 \\
\hline 1993 & 64 & 4,000 & 5,000 & 16,000 & 220,000 & 760,000 & 620,000 & 1.3 & 1.6 & 5.4 & 73 & 250 & 210 \\
\hline 1994 & 38 & 2,700 & 3,000 & 8,300 & 67,000 & 540,000 & 400,000 & .89 & 1.0 & 2.7 & 22 & 180 & 130 \\
\hline 1995 & 75 & 4,300 & 6,000 & 19,000 & 330,000 & 810,000 & 770,000 & 1.4 & 2.0 & 6.3 & 110 & 270 & 260 \\
\hline 1996 & 120 & 5,500 & 10,000 & 35,000 & $2,600,000$ & $1,000,000$ & $1,300,000$ & 1.8 & 3.3 & 12 & 850 & 330 & 430 \\
\hline 2000 & 77 & 2,900 & 4,300 & 20,000 & 260,000 & 510,000 & 660,000 & .95 & 1.4 & 6.6 & 86 & 170 & 220 \\
\hline 2001 & 30 & 1,200 & 1,400 & 6,300 & 36,000 & 210,000 & 240,000 & .38 & .47 & 2.1 & 12 & 71 & 80 \\
\hline 2002 & 93 & 2,600 & 4,300 & 26,000 & 410,000 & 440,000 & 700,000 & .85 & 1.4 & 8.7 & 140 & 150 & 230 \\
\hline 2003 & 52 & 1,600 & 2,400 & 12,000 & 110,000 & 290,000 & 410,000 & .53 & .79 & 4.1 & 37 & 95 & 140 \\
\hline 2004 & 54 & 1,600 & 2,200 & 12,000 & 66,000 & 280,000 & 410,000 & .53 & .73 & 4.1 & 22 & 91 & 130 \\
\hline \multicolumn{14}{|c|}{ Post Falls } \\
\hline 1991 & 230 & 7,700 & 6,100 & 27,000 & 57,000 & 720,000 & 690,000 & 1.1 & 0.85 & 3.7 & 7.9 & 100 & 96 \\
\hline 1992 & 98 & 2,900 & 2,600 & 7,000 & 17,000 & 320,000 & 320,000 & .94 & .83 & 2.3 & 5.5 & 100 & 100 \\
\hline 1993 & 150 & 3,800 & 3,400 & 6,000 & 22,000 & 420,000 & 420,000 & .79 & .70 & 1.3 & 4.7 & 89 & 87 \\
\hline 1999 & 210 & 2,000 & 2,300 & 1,700 & 12,000 & 450,000 & 470,000 & .29 & .34 & .25 & 1.8 & 66 & 70 \\
\hline 2000 & 190 & 1,600 & 1,900 & 1,700 & 11,000 & 400,000 & 430,000 & .25 & .31 & .27 & 1.7 & 65 & 69 \\
\hline 2001 & 76 & 510 & 660 & 870 & 4,600 & 140,000 & 160,000 & .21 & .27 & .36 & 1.9 & 57 & 64 \\
\hline 2002 & 220 & 1,300 & 1,600 & 2,800 & 14,000 & 390,000 & 420,000 & .18 & .23 & .40 & 2.0 & 56 & 60 \\
\hline 2003 & 130 & 660 & 940 & 2,300 & 8,300 & 250,000 & 280,000 & .16 & .22 & .55 & 2.0 & 59 & 66 \\
\hline 2004 & - & - & - & - & - & - & - & - & - & - & - & - & - \\
\hline
\end{tabular}




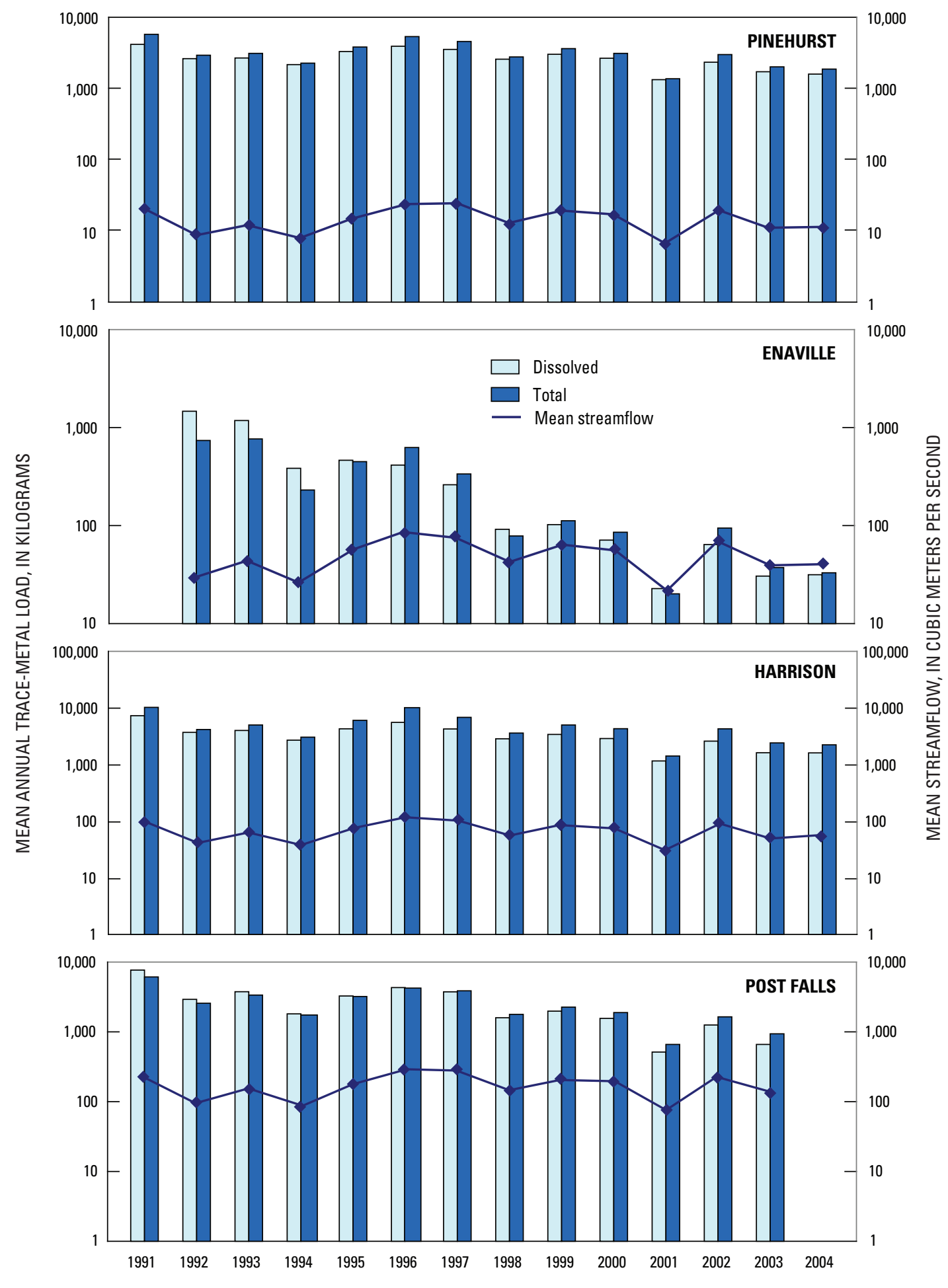

\section{A. CADMIUM}

Figure 7. Estimated long-term mean annual dissolved and total trace-metal loads and mean streamflow at four streamflow-gaging stations in the Spokane River basin, Idaho. Long-term models used records for the periods: Enaville (1992-2004), Pinehurst, Harrison (1991-2004), and Post Falls (1991-2003). 

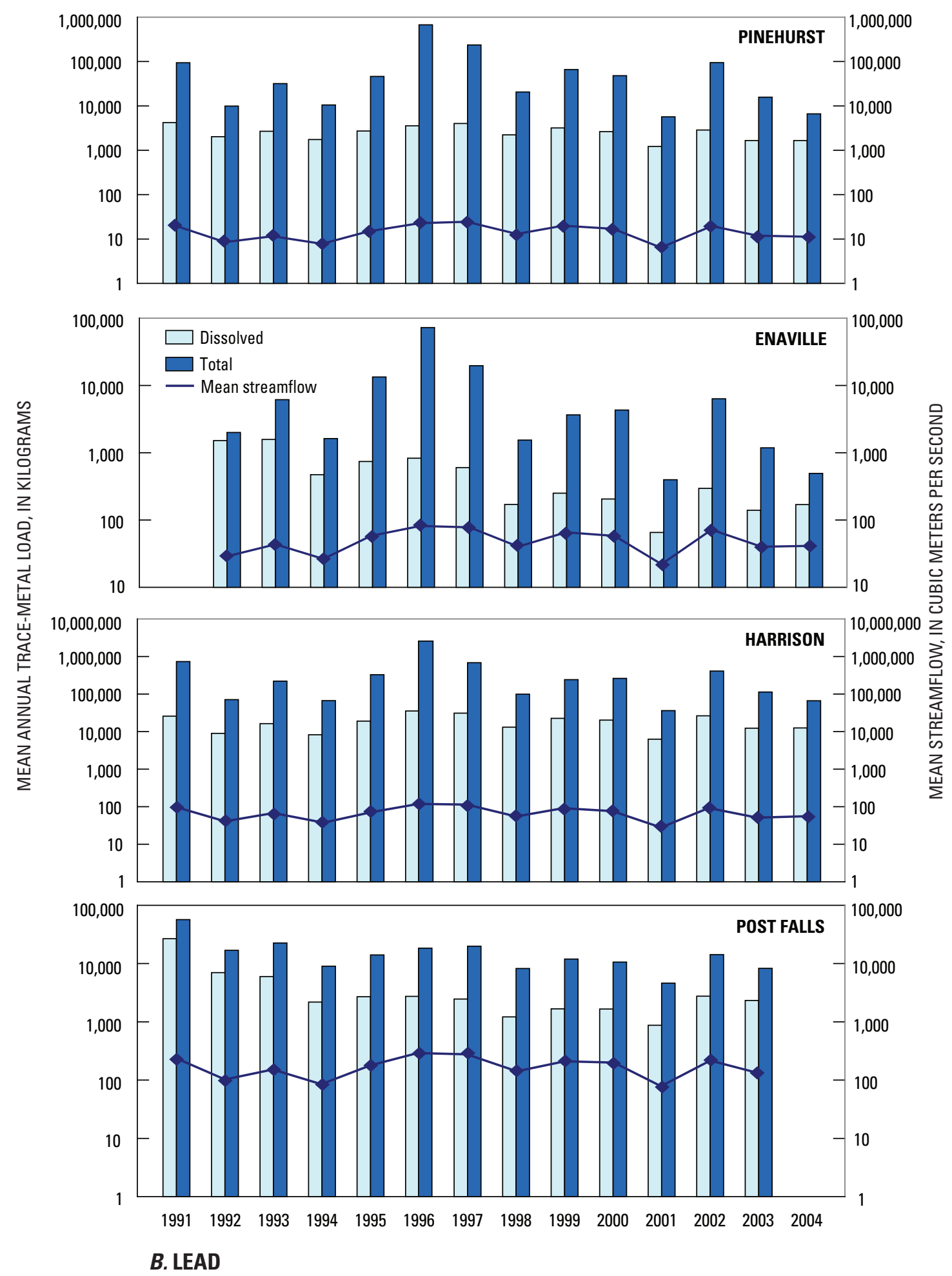

Figure 7.-Continued. 


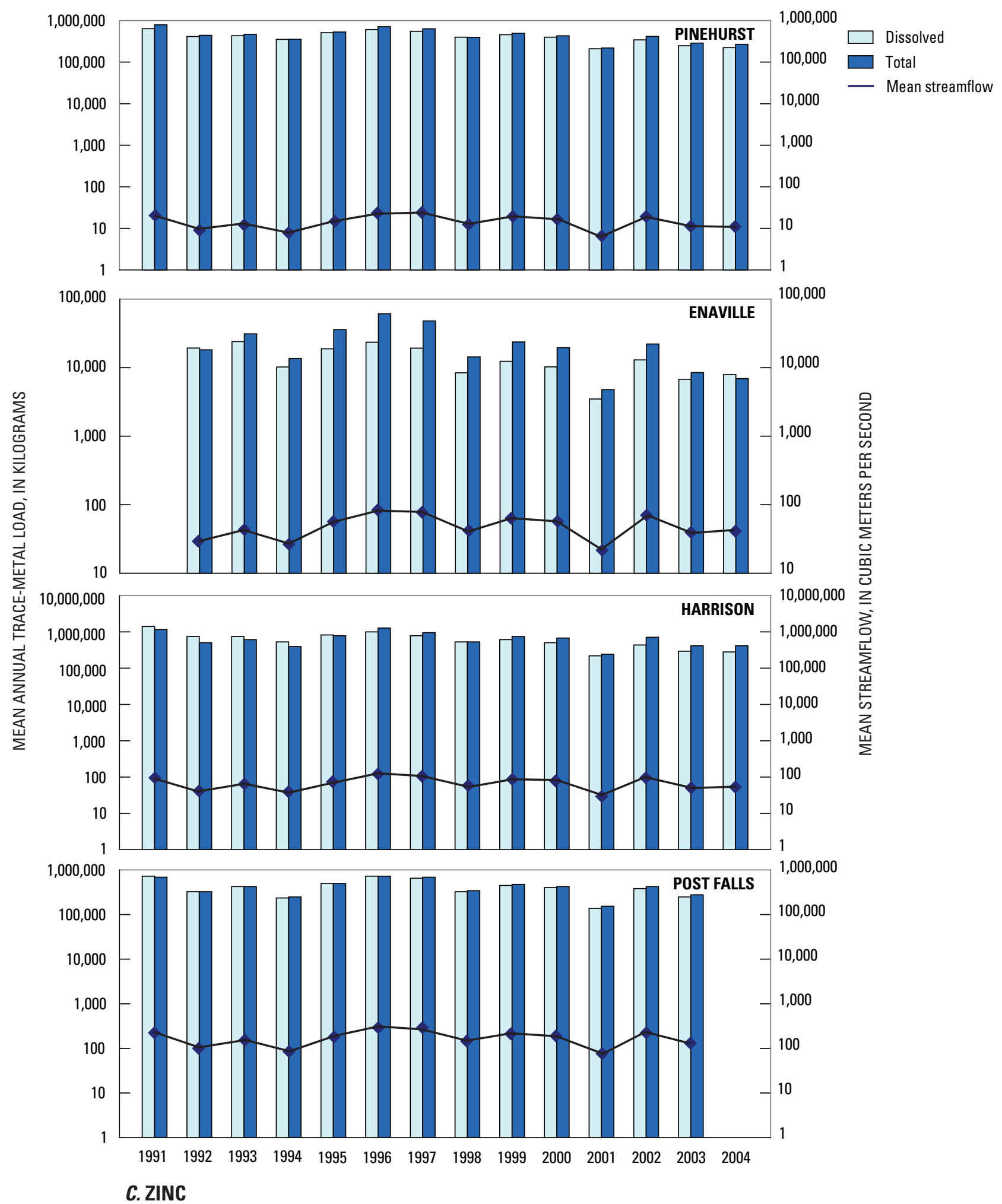

Figure 7.-Continued. 


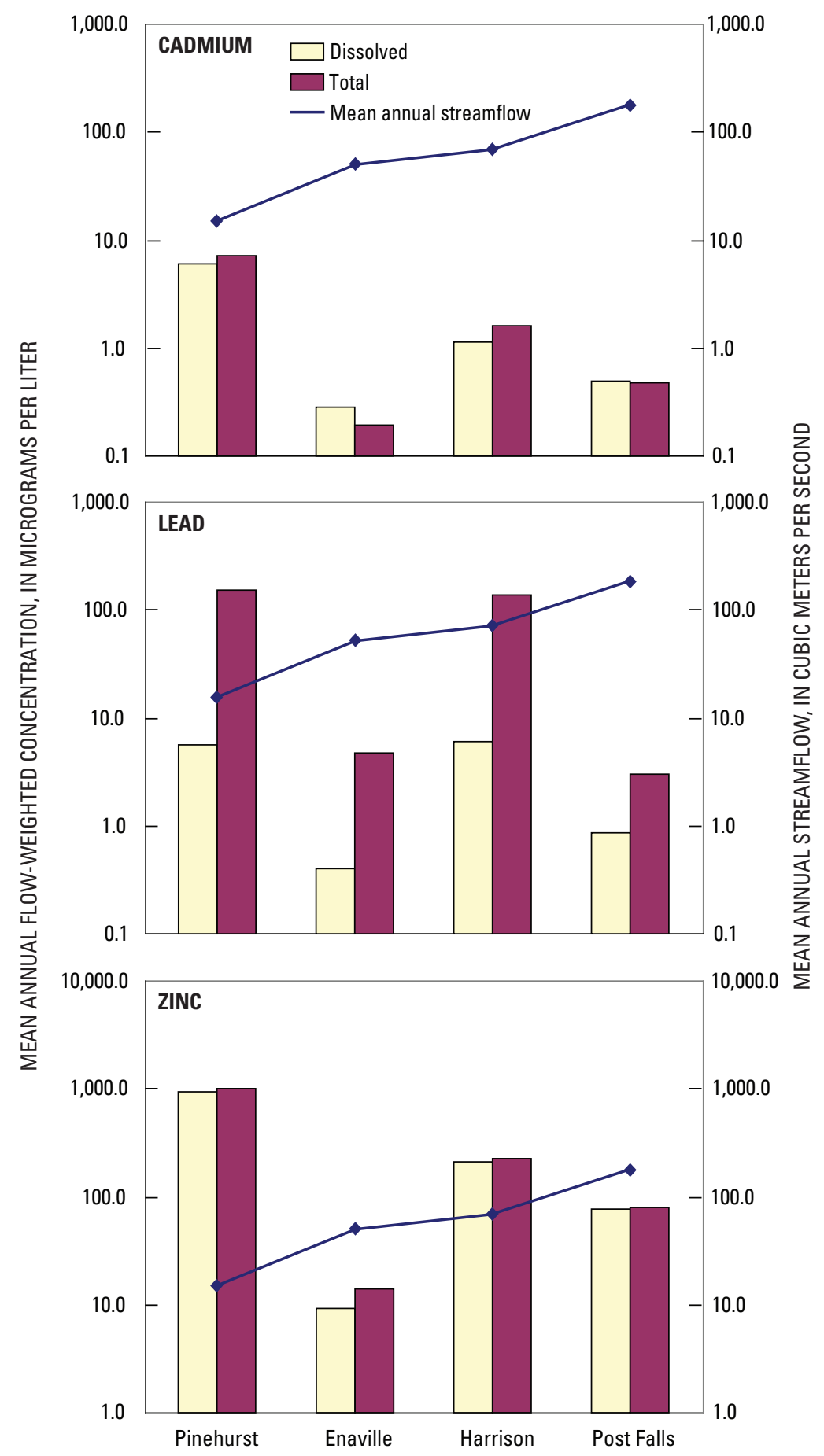

Figure 8. Mean annual flow-weighted concentrations of dissolved and total cadmium, lead, and zinc and mean annual streamflow at four streamflowgaging stations in the Spokane River basin, Idaho. Long-term models used records for the periods: Enaville (1992-2004), Pinehurst, Harrison (1991-2004), and Post Falls (1991-2003). 
Table 8. Comparison of short- and long-term trace-metal load estimates for four streamflow-gaging stations in the Spokane River basin, Idaho.

[All values are in kilograms. Short-term records are for 1999-2004. Long-term records are for the periods: Enaville (1992-2004), Pinehurst, Harrison (19912004), and Post Falls (1991-2003). Symbols: -, no estimate]

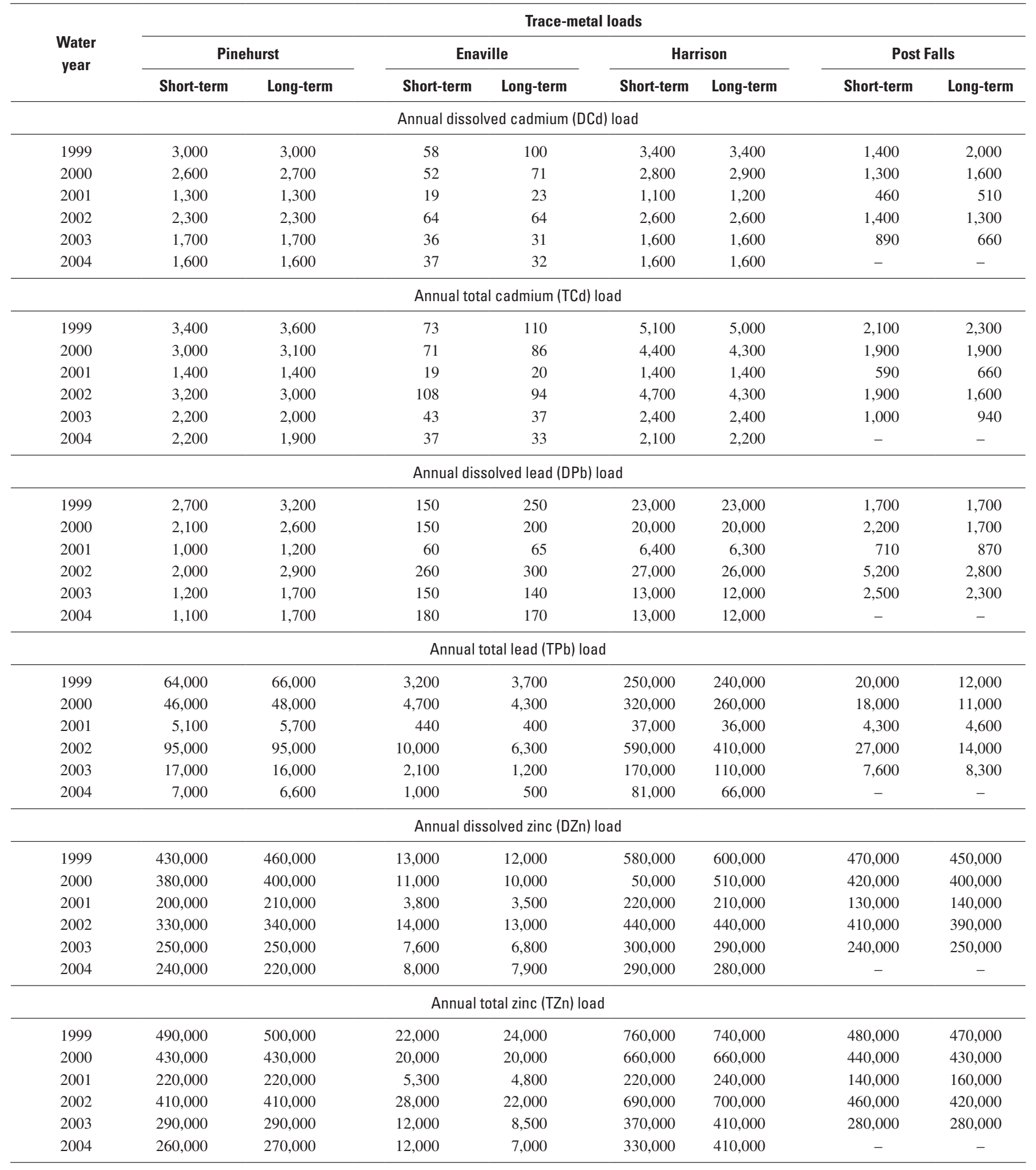



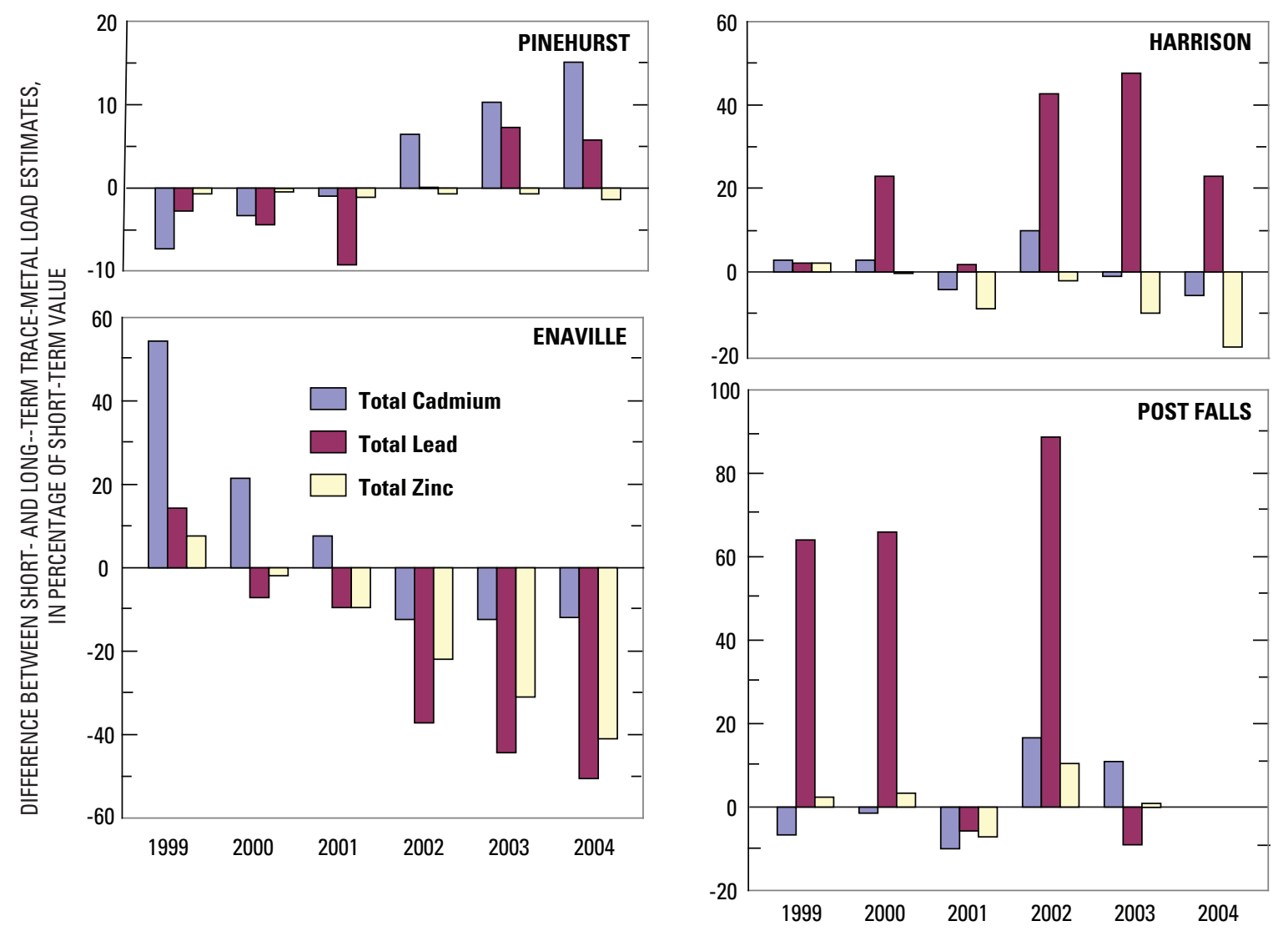

Figure 9. Comparison of short- and long-term trace-metal load estimates at four streamflow-gaging stations in the Spokane River basin, Idaho. Short-term models used records from 1999-2004. Long-term models are based on records for the periods: Enaville (1992-2004), Pinehurst, Harrison (1991-2004), and Post Falls (1991-2003). Load estimates were not made at Post Falls for 2004. 


\section{Temporal Trends in Long-Term Metal Load Estimates}

To gain a better understanding of metal loading through time, the long-term annual trace metal load estimates were evaluated for possible temporal trends. LOADEST results include information on trends in the form of a statistically significant coefficient for a "time" term (labeled " $f$ " in tables 2 and $\underline{6}$ ) in the regression equation. If present, a negative coefficient signifies an overall downward trend during the estimation period; a positive term indicates an upward trend. More complex changes with time are indicated by the presence of a statistically significant "time-squared" $(t 2)$ term in addition to a time term. In this study, a $p$-value of less than or equal to 0.05 (greater than or equal to the 95 percent confidence level) was considered statistically significant. According to the LOADEST results, all four long-term sites showed significant downward trends for DCd, TCd, DZn, and $\mathrm{TPb}$. In addition, Enaville and Post Falls showed significant downward trends for DPb and TZn loads; Harrison TZn loads also decreased significantly with time. No gaging stations showed an increasing trend.

Metal loads and FWCs at Enaville generally decreased with time from 1992-2004, but some explanation is needed for the unusually smooth descending curve displayed by the annual mean FWCs of DCd (fig. 10), in which estimates ranged from 1.6 to $0.02 \mu \mathrm{g} / \mathrm{L}$ DCd. Measured concentrations of DCd were low at Enaville. Of the 86 concentration measurements used in the calibration file, 68 were censored data, for example, below the minimum detection limit (MDL). The 18 measured concentrations above the MDL ranged from 0.02 to $1.0 \mu \mathrm{g} / \mathrm{L}$. Analytical precision improved during the estimation period and the MDLs changed from 1 to $0.04 \mu \mathrm{g} / \mathrm{L}$ in 2001 . The LOADEST software is able to accommodate varying detection limits and applies statistical methods to enable use of censored data in the regression. The regular shape of the time-series graph of DCd FWC likely is an expression of combined effects of the high proportion of censored data for this constituent, modeling process itself, and actual decreases in FWC with time. A similar pattern is exhibited by DCd at Post Falls, another station with abundant censored calibration data. An example from Pinehurst of TCd FWCs calculated from data with no censored data among 77 samples is given for comparison (fig. 10).

A simple but useful independent test for trends in time-series data is the non-parametric Mann-Kendall trend test. Generally, this test determines whether values tend to monotonically increase or decrease with time. Because this test is non-parametric, the data need not be assumed to have a normal distribution. This is a valid test as long as no serial correlation is present in the data (Helsel and Hirsch, 1995). Because annual data were analyzed, there was no sensitivity to seasonal changes. The relatively long 13- or 14-year interval helps minimize the effects of extreme years.

The results of applying the Mann-Kendall trend test to estimated annual load and FWC data are compared with the trend information from the long-term LOADEST regression results in table 9 .

Results of the two types of trend analysis agree in most cases. For example, both methods indicate that all four long-term sites had statistically significant (with 95 percent confidence) decreasing trends for Cd loads and FWCs for the estimation period, with a few cases of disagreement; for instance, the methods gave contradictory results for $\mathrm{TZn}$ at Pinehurst and at Post Falls.

It should be noted that the Mann-Kendall test results simply show whether an overall monotonic change exists for the entire 13- or 14-year period. Therefore, trends for shorter intervals in this period are not precluded. For example, based on the Mann-Kendall test, FWCs of DPb show a significant increasing trend for 1999-2003 at Post Falls. The statistical results must be viewed in the context of other information known about the data and about the system as a whole. 


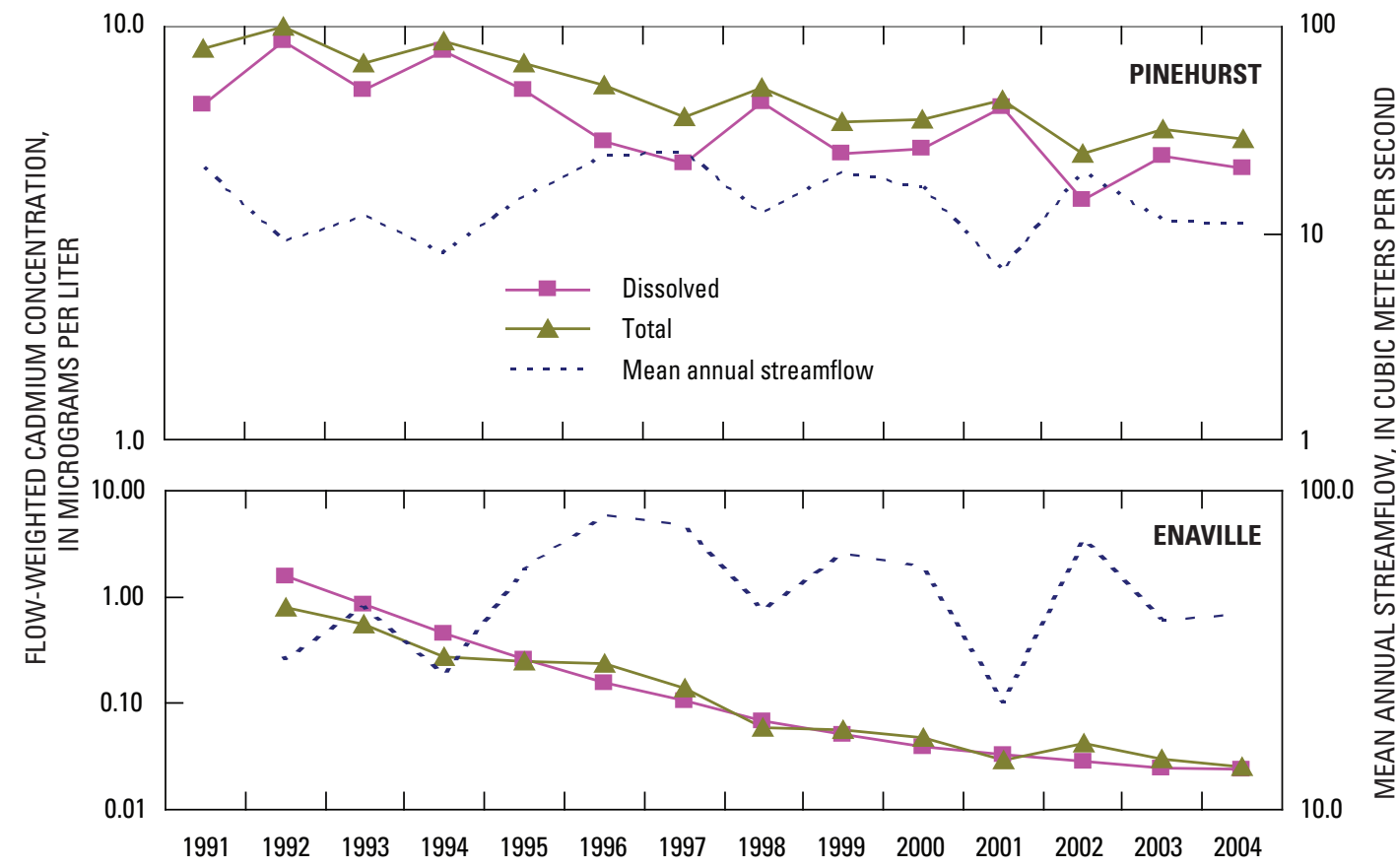

Figure 10. Estimated flow-weighted concentration of dissolved and total cadmium and mean annual streamflow at South Fork Coeur d'Alene River at Pinehurst, water years 1991-2004 and North Fork Coeur d'Alene River at Enaville, Idaho, water years 1992-2004.

Table 9. Comparison of trend analysis results for trace-metal loads and flow-weighted concentrations based on the Mann-Kendall test and LOADEST regression analysis for four streamflow-gaging stations in the Spokane River basin, Idaho, water years 1991-2004.

[Abbreviations: Y, statistically significant downward trend at greater than 95-percent confidence level; $\mathrm{N}$, no significant trend. -, comparison not made]

\begin{tabular}{|c|c|c|c|c|c|c|c|c|}
\hline \multirow{3}{*}{ Trace metal } & \multicolumn{8}{|c|}{ Trace-metal loads } \\
\hline & \multicolumn{2}{|c|}{ Pinehurst } & \multicolumn{2}{|c|}{ Enaville } & \multicolumn{2}{|c|}{ Harrison } & \multicolumn{2}{|c|}{ Post Falls } \\
\hline & Mann-Kendall & LOADEST & Mann-Kendall & LOADEST & Mann-Kendall & LOADEST & Mann-Kendall & LOADEST \\
\hline Dissolved cadmium (DCd) & $\mathrm{Y}$ & $\mathrm{Y}$ & $\mathrm{Y}$ & $\mathrm{Y}$ & $\mathrm{Y}$ & $\mathrm{Y}$ & $\mathrm{Y}$ & $\mathrm{Y}$ \\
\hline Total cadmium (TCd) & $\mathrm{Y}$ & $\mathrm{Y}$ & $\mathrm{Y}$ & $\mathrm{Y}$ & $\mathrm{Y}$ & $\mathrm{Y}$ & $\mathrm{Y}$ & $\mathrm{Y}$ \\
\hline Dissolved lead (DPb) & $\mathrm{Y}^{1}$ & $\mathrm{~N}$ & $\mathrm{Y}$ & $\mathrm{Y}$ & $\mathrm{N}$ & $\mathrm{N}$ & $\mathrm{Y}$ & $\mathrm{Y}$ \\
\hline \multirow[t]{2}{*}{ Total zinc (TZn) } & $\mathrm{Y}$ & $\mathrm{N}$ & $\mathrm{Y}$ & $\mathrm{Y}$ & $\mathrm{Y}^{1}$ & $\mathrm{Y}$ & $\mathrm{N}$ & $\mathrm{Y}$ \\
\hline & \multicolumn{8}{|c|}{ Flow-weighted concentrations } \\
\hline Dissolved cadmium (DCd) & $\mathrm{Y}$ & - & $\mathrm{Y}$ & - & $\mathrm{Y}$ & - & $\mathrm{Y}$ & - \\
\hline Total cadmium (TCd) & $\mathrm{Y}$ & - & $\mathrm{Y}$ & - & $\mathrm{Y}$ & - & $\mathrm{Y}$ & - \\
\hline
\end{tabular}

${ }^{1}$ Result was statistically significant at the 90 - to 95 -percent confidence level. 


\section{Summary}

Streamflow and trace-metal chemistry data collected at 10 U.S. Geological Survey streamflow-gaging stations in the Spokane River basin were used as input for the U.S. Geological Survey software, LOADEST, to estimate annual loads and mean flow-weighted concentrations of total and dissolved cadmium, lead, and zinc for 1999 to 2004. These estimates yielded valuable information about processes of metal storage and transport, and demonstrated that water quality data are a great aid in understanding these processes.

Cadmium composed less than 1 percent of the total metal load at all stations; mean annual total cadmium loads for 1999-2004 ranged from 39 kilograms at Amy Gulch to 3,400 kilograms at Harrison. Overall, mean annual total cadmium loads were lowest at the stations at Amy Gulch, Enaville, Ninemile Creek, and Canyon Creek, and highest at Harrison, Pinehurst, Post Falls, and Elizabeth Park.

Dissolved cadmium typically ranged from about 70 percent to about 100 percent of the total cadmium load. The ratio of dissolved to total cadmium was higher at stations where ground water was a volumetrically important component of the streamflow. Ratio of dissolved cadmium to total cadmium also was higher at most stations during low-flow years such as 2001 , because of the greater relative contribution of ground water to streamflow. Dissolved cadmium/total cadmium ratios about 0.9 and greater were estimated at stations upstream from Pinehurst. The lowest dissolved cadmium/total cadmium ratio was estimated at Harrison.

Total lead constituted from 6 to 42 percent of the total load at stations upstream of Coeur d'Alene Lake and from 2 to 4 percent at stations downstream of the lake. Gaging stations at Amy Gulch, Ninemile Creek, and Enaville yielded the lowest mean annual estimated total lead loads in the basin. By far the highest overall mean total lead load in the basin was estimated at Harrison. Maximum total lead loads at eight stations in the basin were estimated for 2002, which may reflect flushing of accumulated lead-laden sediment stored in the stream channels during 2001, a low-flow year.

The ratio of dissolved lead to total lead varied in time and space and reflected the relative contribution of ground water to total streamflow and the variation in the amount of suspended particulate and (or) colloidal material. Dissolved lead ranged from less than 10 percent to nearly 30 percent of the total lead load.

Zinc composed more than 90 percent of the total metal load at 8 of the 10 gaging stations examined in this study. Mean annual total zinc loads for 1999-2004 ranged from 510,000 kilograms at Harrison to 14,000 kilograms at Amy Gulch. Low annual total zinc loads at Amy Gulch and at
Enaville likely reflect the low availability of metals in the source areas upstream of these stations. Estimated mean annual total zinc loads at Harrison far exceeded those at any other station. The three highest estimated annual total zinc loads were at Harrison, Post Falls, and Pinehurst. Total zinc loads also were high at Outlet, Post Falls, and Long Lake.

Dissolved zinc/total zinc ratios typically were greater than 0.8 at most gaging stations. Although estimated total zinc loads were relatively low in 2001 due to the effect of streamflow on the load calculation, the ratio of dissolved zinc to total zinc load was higher in 2001 than in other years, owing to less dilution and a higher proportion of ground water input to streamflow.

Notable systematic differences between total metal loads at stations in different parts of the basin are partly due to the direct relation between streamflow and load. Above Coeur d'Alene Lake, gaging stations with higher streamflow generally yielded higher loads. However, the total metal loads at the three stations downstream of Coeur d'Alene Lake, where mean streamflow is 2-3 times higher than at Harrison, are relatively small. Based on the dissolved metal data and the relative proportions of metals, this observation was interpreted as lead trapped by sediments in Coeur d'Alene Lake and the transmission of cadmium and zinc.

Flow-weighted concentrations (FWCs) calculated from the estimated loads were examined to enhance the interpretation of metal load estimates, which were influenced by large spatial and temporal differences in streamflow. Total cadmium FWCs ranged from 14 to $0.04 \mu \mathrm{g} / \mathrm{L}$ and were highest at Ninemile and Canyon Creeks and lowest at Enaville.

Both total cadmium loads and mean streamflow were low at Enaville, indicating overall low metal contribution from the North Fork Coeur d'Alene River. The combination of low total cadmium FWCs and high total cadmium loads at gaging stations downstream of Coeur d'Alene Lake was attributed to the effects of downstream dilution with higher streamflow.

Total lead FWCs were highest at Ninemile Creek, Canyon Creek, and Harrison. The elevated total lead FWCs at Harrison confirmed that the high total lead loads at this station were not simply due to higher streamflow. Conversely, relatively low total lead loads combined with high total lead FWCs at Ninemile and Canyon Creeks reflect relatively low streamflow but high concentrations of total lead.

Total zinc FWCs also demonstrate the strong effect of streamflow on load calculations, and confirm source areas for zinc in the basin. Total zinc FWCs at Ninemile and Canyon Creeks are by far the highest in the basin but contribute among the lowest total zinc loads due to their relatively low streamflow. Conversely, stations downstream of Coeur d'Alene Lake exhibit among the lowest total zinc FWCs, but total zinc load estimates are high because of their high mean streamflow relative to other stations in the basin. 
An earlier version of the LOADEST software was used in a previous study to estimate loads for WY1999-2001 for many of the same sites included in this report. Overall, there was good agreement between results of this study and the previous study. However, notable discrepancies are attributable to important differences in streamflow for 1999-2001 versus 1999-2004. Very low streamflow in 2001 strongly influenced Clark's results because that year's data constituted a greater proportion of total available data, whereas, 2001 data were a smaller proportion of the available data for this study. Because the software uses the relation between streamflow and concentration to calculate the regressions, estimated loads during the overlapping years were somewhat different for the two data sets.

Long-term regression models for 1991 to 2003 or 2004 were developed and annual trace-metal loads and FWCs were estimated for Enaville, Pinehurst, Harrison, and Post Falls to better understand the variability of metal loading with time. Long-term load estimates were compared with those for 1999-2004 to examine the robustness of the two differently calibrated models. Long-term estimates mirror the results for 1999-2004 in terms of the mean annual metal loads. The largest mean loads for the estimation period were measured at Harrison and Pinehurst. The largest estimated loads were in 1996 and 1997 (both very high streamflow years) at all four stations; high loads also were measured in 1991. The lowest loads prior to 1999 were in 1994 and 1998. Although low estimated loads in 1994 probably reflect low streamflow, estimated loads in 1998 may have reflected both low streamflow and lack of sufficient time for metals to accumulate upstream after unusually high flows had scoured the channels during 1996 and 1997.

The long- and short-term estimates for these four sites for 1999-2004, the interval common to both estimates, were similar, but with notable differences. Because the LOADEST software uses the relation between streamflow and concentration to perform the regressions, and the calibration data files for 1999-2004 represented a smaller data set than the 1991-2004 data set, different regression models resulted. Differing results demonstrate the importance of assuring that models not be extrapolated beyond the time interval and range of streamflow represented by the input data used to calibrate them.

LOADEST results suggested that statistically significant downward trends during 1991-2004 were at Enaville, Pinehurst, Harrison, and Post Falls for dissolved cadmium, total cadmium, total lead, and dissolved zinc. Additionally, data from Enaville and Post Falls showed significant downward trends for dissolved lead and total zinc loads; Harrison total zinc loads also diminished with time. The Mann-Kendall trend test also was applied to the load data and the results agreed with the LOADEST trend results in most cases, but gave contradictory results for total zinc at Pinehurst and Post Falls. The Mann-Kendall test indicated significant downward trends in FWCs for all constituents except dissolved lead and total lead at Harrison and for total lead at Pinehurst.

\section{References Cited}

Akaike, H., 1981, Likelihood of a model and information criterion: Journal of Econometrics, v. 16, p. 3-14.

Beckwith, M.A., 1998, Concepts for monitoring water quality in the Spokane River Basin, Northern Idaho and Eastern Washington: U.S. Geological Survey Open-File Report 98-534, 25 p.

Bookstrom, A.A., Box, S.E., Campbell, J.K., Foster, K.I., and Jackson, B.L., 2001, Lead-rich sediments, Coeur d'Alene River Valley, Idaho - area, volume, tonnage, and lead content: U.S. Geological Survey Open-File Report 01-140, 44 p.

Bortleson, G.C., Cox, S.E., Munn, M.D., Schumaker, R.J., Block, E.K., Bucy, L.R., and Cornelius, S.B., 1994, Sediment-quality assessment of Franklin D. Roosevelt Lake and the upstream reach of the Columbia River, Washington, 1992: U.S. Geological Survey Open-File Report 94-315, $130 \mathrm{p}$.

Buchanan, T.J., and Somers, W.P., 1968, Stage measurements at gaging stations: U.S. Geological Survey Techniques of Water-Resources Investigations, book 3, chap. A7, 28 p.

Buchanan, T.J., and Somers, W.P., 1969, Discharge measurements at gaging stations: U.S. Geological Survey Techniques of Water-Resources Investigations, book 3, chap. A8, 65 p.

Carter, R.W., and Davidian, J., 1968, General procedure for gaging streams: U.S. Geological Survey Techniques of Water-Resources Investigations, book 3, chap. A6, 13 p.

Clark, G.M., 2002, Occurrence and transport of cadmium, lead, and zinc in the Spokane River Basin, Idaho and Washington, Water Years 1999-2001, U.S. Geological Survey Water-Resources Investigations Report 02-4183, $37 \mathrm{p}$.

Clark, G.M., Caldwell, R.R., Maret, T.R., Bowers, C.L., Dutton, D.M., and Beckwith, M.A., 2004, Water quality in the Northern Rockies Intermontane Basins, Idaho, Montana, and Washington, 1999-2001: U.S. Geological Survey Circular 1235, $35 \mathrm{p}$. 
Delong, L.L., Thompson, D.B., and Lee, J.K., 1997, The computer program FourPt (version 95.01)-a model simulating one-dimensional, unsteady, open-channel flow: U.S. Geological Survey Water-Resources Investigations Report 97-4016, 69 p.

Edwards, T.K., and Glysson, G.D., 1988, Field methods for measurement of fluvial sediment: U.S. Geological Survey Open-File Report 86-531, 118 p.

Fishman, J.J., ed., 1993, Methods of analysis by the U.S. Geological Survey National Water Quality Laboratorydetermination of inorganic and organic constituents in water and fluvial sediments: U.S. Geological Survey Open-File Report 93-125, 217 p.

Fousek, R.S., 1996, Trace-element distributions in the sediments of the flood plain and river banks of the South Fork and Coeur d'Alene Rivers, Shoshone and Kootenai Counties, Idaho: Auburn, Ala., Auburn University, M.S. thesis, $310 \mathrm{p}$.

Friedman, L.C., and Erdmann, D.E., 1982, Quality assurance practices for the chemical and biological analyses of water and fluvial sediments: U.S. Geological Survey Techniques of Water Resources Investigations, book 5, chap. A6, 181 p.

Grosbois, C.A., Horowitz, A.J., Smith, J.J., and Elrick, K.A., 2001, The effect of mining and related activities on the sediment-trace element geochemistry of Lake Coeur d'Alene, Idaho, USA, Part III, Downstream effects-the Spokane River Basin: Hydrological Processes, v. 15, p. 855-875.

Hartz, M., 1993, Point and nonpoint source contributions of trace heavy metals to the South Fork Coeur d'Alene River, Shoshone County, Idaho, 1989-1990: Boise, Idaho Department of Health and Welfare, Division of Environmental Quality, Water Quality Status Report no. 111,69 p.

Helsel, D.R., and Hirsch, R.M., 1995, Statistical methods in water resources: New York, Elsevier, 522 p.

Horowitz, A.J., Elrick, K.A., Robbins, J.A., and Cook, R.B., 1995, A summary of the effects of mining and related activities on the sediment-trace element geochemistry of Lake Coeur d'Alene, Idaho, USA: Journal of Geochemical Exploration, v. 52, p. 135-144.

Long, K.R., 1998, Production and disposal of mill tailings in the Coeur d'Alene mining region, Shoshone County, IdahoPreliminary estimates: U.S. Geological Survey Open-File Report 98-595, 14 p.
Maret, T.R., and Skinner, K.D., 2000, Concentrations of selected trace elements in fish tissue and streambed sediment in the Clark Fork-Pend Oreille and Spokane River Basins, Washington, Idaho, and Montana, 1998: U.S. Geological Survey Water-Resources Investigations Report 00-4159, 26 p.

Mueller, D.K., Martin, J.D., and Lopes, T.J., 1997, Qualitycontrol design for surface-water sampling in the National Water-Quality Assessment Program: U.S. Geological Survey Open-File Report 97-223, 17 p.

Pritt, J.W., and Raese, J.W., eds., 1995, Quality assurance/ quality control manual, National Water Quality Laboratory: U.S. Geological Survey Open-File Report 95-443, 35 p.

Runkel, R.L., Crawford, C.G., and Cohn, T.A., 2004, Load Estimator (LOADEST): A FORTRAN Program for Estimating Constituent Loads in Streams and Rivers: U.S. Geological Survey Techniques and Methods Book 4, Chapter A5, 69 p.

Spruill, T.B., 1993, Preliminary evaluation of hydrogeology and ground-water quality in valley sediments in the vicinity of Killarney Lake, Kootenai County, Idaho: U.S. Geological Survey Water-Resources Investigations Report 93-4091, $41 \mathrm{p}$.

URS-Greiner, Inc. and CH2M-Hill, Inc.,2001, Remedial investigation report, Coeur d'Alene Basin, remedial investigation/feasibility study, vol. 1, part 7, Summary: Response action contract no. 68-W-98-228, prepared for U.S. Environmental Protection Agency, Region 10, Seattle, Wash., variously paged.

U.S. Environmental Protection Agency, 1997, The incidence and severity of sediment contamination in surface waters of the United States, v. 1-3: U.S. Environmental Protection Agency, Office of Water, EPA 823-R-97-006, -007, and -008 .

Woods, P.F., 2001a, Concentrations and loads of cadmium, lead, and zinc measured on the ascending and descending limbs of the 1999 snowmelt-runoff hydrographs for nine water-quality stations, Coeur d'Alene River Basin, Idaho: U.S. Geological Survey Open-File Report 00-310, 42 p.

Woods, P.F., 2001b, Concentrations and loads of cadmium, lead, and zinc measured during the 1999 water year within the Spokane River Basin, Idaho and Washington: U.S. Geological Survey Open-File Report 00-441, 32 p.

Woods, P.F., and Beckwith, M.A., 1997, Nutrient and traceelement enrichment of Coeur d'Alene Lake, Idaho: U.S. Geological Survey Water-Supply Paper 2485, 93 p. 
This page left intentionally blank. 
Manuscript approved for publication, July 25, 2006

Prepared by the USGS Publishing Network,

Publishing Service Center, Tacoma, Washington

Bob Crist

Debra Grillo

Virginia Renslow

Bobbie Jo Richey

For more information concerning the research in this report, contact the Idaho Water Science Center Director,

230 Collins Road

Boise, Idaho 83702-4520

http://id.water.usgs.gov 


\section{$\mathbb{Z}$ 8}

음
0
ㅇ

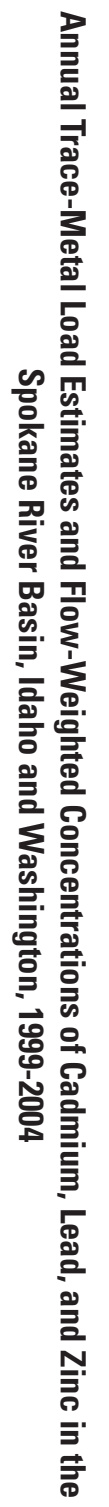

